\title{
Structure-Based Design of Selective, Covalent G Protein- Coupled Receptor Kinase 5 Inhibitors
}

Rachel Rowlands, M. Claire Cato, Helen V. Waldschmidt, Renee Bouley, Qiuyan Chen, Larisa Avramova, Scott D. Larsen, John J.G. Tesmer, Andrew D. White. 
General Chemistry: All reagents from commercial sources were used without further purification unless otherwise noted. ${ }^{1} \mathrm{H}-\mathrm{NMR}$ spectra were taken in DMSO-d6, MeOD or $\mathrm{CDCl}_{3}$ at room temperature on: Varian MR $400 \mathrm{MHz}$; Varian Vnmrs $500 \mathrm{MHz}$; and Varian Vnmrs $700 \mathrm{MHz}$ instruments. The reported chemical shifts for the ${ }^{1} \mathrm{HNMR}$ spectra were recorded in parts per million ( $\mathrm{ppm}$ ) on the $\delta$ scale from an internal tetramethylsilane (TMS) standard $(0.0 \mathrm{ppm})$. Small molecule mass spectrometry data was measured using a Waters Corporation Micromass LCT or Agilent6230 Q-TOF instrument. HPLC was used to determine purity of compounds on an Agilent 1100 series with an Agilent Zorbax Eclipse Plus-C18 column. A gradient of $10-90 \%$ acetonitrile/water over 6 min followed by $90 \%$ acetonitrile/water for 7 min was used with detection at $254 \mathrm{~nm}$.

Intact Protein MS and Tandem MS/MS: Intact protein MS was acquired with a Phenomenex C4 column paired with an Agilent 6545 Q-TOF LC/MS. For intact MS and Tandem MS, all samples were prepared with $20 \mu \mathrm{M}$ GRK in assay buffer (see below), 1 $\mathrm{mM}$ compound, and incubated at $4{ }^{\circ} \mathrm{C}$ for $3 \mathrm{hr}$ before being quenched with $1.0 \mu \mathrm{L}$ of formic acid. In Tandem MS/MS, we chose Glu-C as the restricting enzyme to avoid small fragments with mass-to-charge ratios below the limit of detection of our instrument. ${ }^{1}$ All samples were digested with Glu-C sequencing enzyme, procured from Sigma Aldrich (Roche Life Sciences subsidiary) and used without further purification. MS/MS experiments were run on a nano-LC (Dionex RSLC-nano) with an Orbitrap Fusion Tribrid ETD mass spectrometer. This work was conducted by the Proteomics Resource Facility at the University of Michigan.

Inhibition Assays: For compounds 4-9, IC 50 values for human GRK5, bovine GRK2, and bovine GRK1 were determined using a radiometric assay as follows. $50 \mathrm{nM}$ GRK was incubated with $500 \mathrm{nM}$ porcine brain tubulin (Cytoskeleton) and $0-333 \mu \mathrm{M}$ inhibitor in 20 $\mathrm{mM}$ HEPES pH 7.0, $2 \mathrm{mM} \mathrm{MgCl}_{2}, 0.025 \%$ dodecylmaltoside (DDM), 3\% DMSO for 20-30 min for GRK1 and 2 and 0-1 hr for GRK5, as denoted in Table 1, on ice, prior to initiation with the addition of $5 \mu \mathrm{M}$ ATP supplemented with radioactive [ $\left.\gamma^{-}{ }^{32} \mathrm{P}\right]-A T P$ (PerkinElmer Life Sciences). Reactions were quenched at 5 min by addition of $6 \mu \mathrm{L}$ of $4 \mathrm{X}$ SDS gel loading dye to the $6 \mu \mathrm{L}$ reactions. $8 \mu \mathrm{L}$ samples were separated on a $4-15 \%$ Criterion TGX precast gel (Bio-Rad). Experiments were performed with an $n=3$ in duplicate.

For the remaining compounds $16 \mathbf{a}-\mathbf{1 6 j}, I C_{50}$ values for human GRK5, bovine GRK2, bovine GRK6, and bovine GRK5-C474S were similarly determined with the following differences. Inhibitors were assessed over the range of $1 \mathrm{nM}-1 \mathrm{mM}$ in $20 \mathrm{mM}$ HEPES pH $7.5,10 \mathrm{mM} \mathrm{NaCl}, 10 \mathrm{mM} \mathrm{MgCl}_{2}, 2 \mathrm{mM}$ DTT after a $4 \mathrm{hr}$ incubation at room temperature prior to reaction initiation with ATP. Reactions were quenched at 8 min by transferring 10 $\mu \mathrm{L}$ reaction into $5 \mu \mathrm{L} 4 \mathrm{X}$ SDS gel loading dye. $10 \mu \mathrm{L}$ samples were separated on a $4-15 \%$ Criterion TGX precast gel. These conditions were also used to assess compound $\mathbf{5}$ for GRK5 (4 hr), GRK2, and GRK5-C474S but with the addition of 3\% DMSO (final) to the incubation buffer. Experiments were performed with an $n=3$ except for assays involving 5 against GRK5, GRK6, and GRK5-C474S with $4 \mathrm{hr}$ incubations, which were performed 4 times. 
For compounds $\mathbf{5}$ and $\mathbf{1 6 d}, \mathrm{IC}_{50}$ values were also determined when opsin was used as the substrate. $50 \mathrm{nM}$ of GRK5 were preincubated with 0-750 $\mu \mathrm{M}$ inhibitor in buffer containing $20 \mathrm{mM}$ HEPES pH 7.0, $2 \mathrm{mM} \mathrm{MgCl}$, $0.025 \%$ dodecylmaltoside (DDM), $3 \%$ DMSO for $0,30,60$ or 240 min. Rhodopsin in the rod outer segment was exposed to the light for approximately $3 \mathrm{~min}$ right before phosphorylation. $5 \mu \mathrm{M}$ ATP supplemented with radioactive $\left[\gamma_{-}{ }^{32} \mathrm{P}\right]-\mathrm{ATP}$ (PerkinElmer Life Sciences) was added to initiate the reaction. Reactions were quenched at $5 \mathrm{~min}$ by addition of $10 \mu \mathrm{L}$ of $4 \mathrm{X}$ SDS gel loading dye to the $20 \mu \mathrm{L}$ reactions. $12 \mu \mathrm{L}$ samples were separated on a $4-15 \%$ Criterion TGX precast gel (Bio-Rad). Experiments were performed with an $n=2$ for compound 5 an $n=3$ for compound $16 \mathrm{~d}$.

Gels were dried, exposed to a storage phosphor screen overnight, and scanned using a Typhoon scanner. Bands corresponding to phosphorylated tubulin were quantified using ImageQuant, plotted as a function of log[inhibitor], and fit to the three-parameter $\log$ (inhibitor) vs. response model in GraphPad Prism 7.03 to determine the $\mathrm{IC}_{50}$., and mean and standard deviation values were calculated using the column statistics function of GraphPad Prism 7.03.

Standard control compounds are run during each assay to assess consistency across time, experimenters, and subtle changes in assay conditions that are sometimes required to keep some of the compounds soluble and disperse (such as through addition of DDM or $3 \%$ DMSO). Paroxetine, GSK180736A, and CCG215022 were used as controls for compounds 4-9, and CCG215022 for compounds 16a-16j.

Synthetic Protocols:
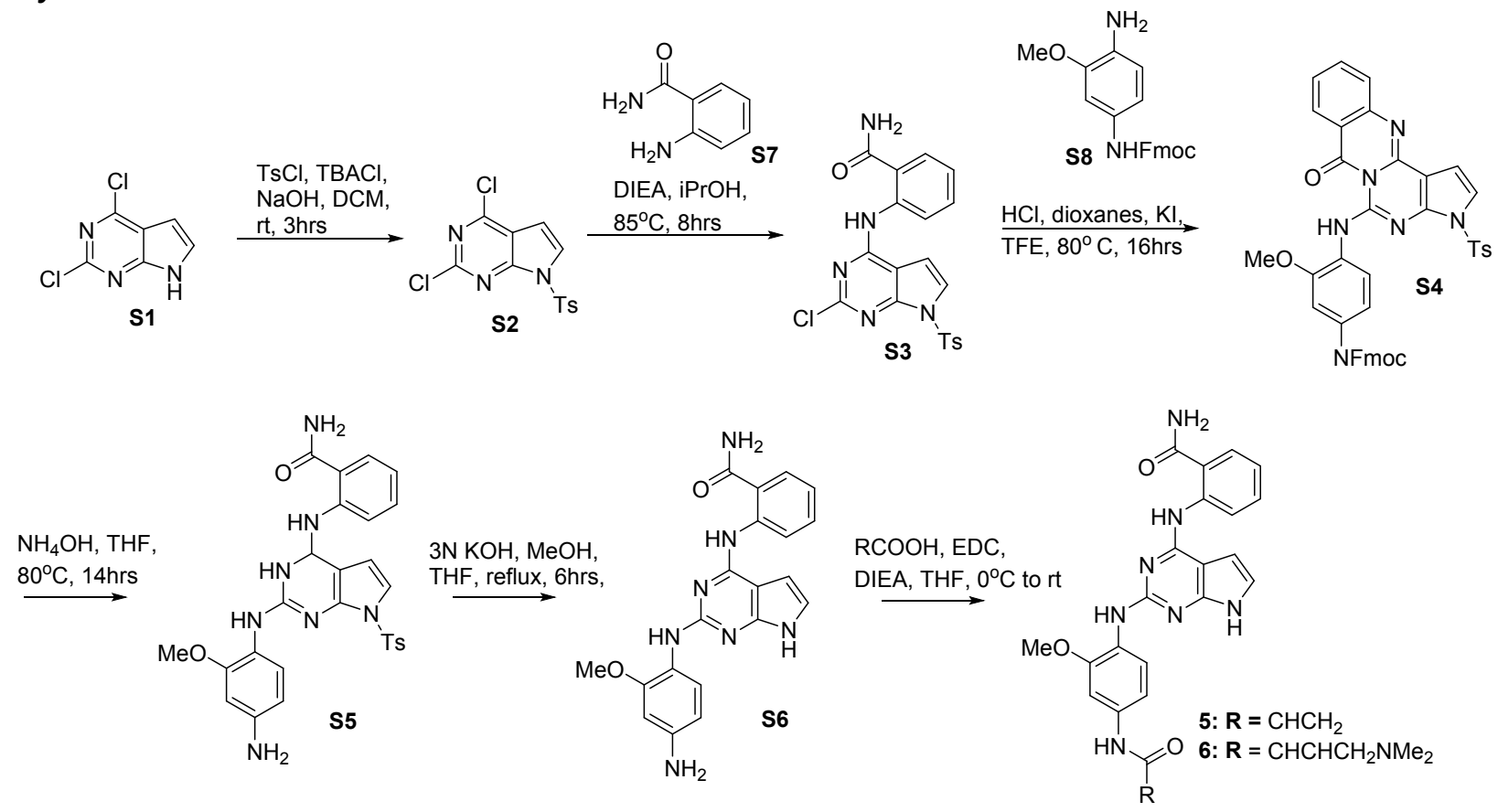

Scheme S1: Synthesis of non-homologated para-substituted analogues $\mathbf{5}$ and $\mathbf{6}$.

2,4-dichloro-7-tosyl-7H-pyrrolo[2,3-d]pyrimidine (S2): To a $100 \mathrm{~mL}$ round bottom flask was added 2,4-dichloro-7H-pyrrolo[2,3-d]pyrimidine $\mathbf{S 1}$ (1.0 g, $5.32 \mathrm{mmol}$ ), 4 - methylbenzene - 1 - sulfonyl 
chloride (1.12 g, $5.85 \mathrm{mmol})$, tetra - butyl ammonium chloride $(0.07 \mathrm{~g}, 0.27 \mathrm{mmol})$, and dichloromethane $(20 \mathrm{~mL})$. Then $6 \mathrm{~N}$ sodium hydroxide $(2.66 \mathrm{~mL}, 15.96 \mathrm{mmol})$ was added dropwise. The slurry was stirred at room temperature vigorously for 1.5 hours going from cloudy to clear. The reaction was then diluted with water and the layers were separated. The organic layer was washed with $\mathrm{NaCl}(1 \mathrm{x})$, and then dried with $\mathrm{MgSO}_{4}$. The $\mathrm{MgSO}_{4}$ was filtered off and the filtrate was then concentrated. The resulting off white solid was purified using $100 \%$ dichloromethane to give the title compound as a white solid $(1.64 \mathrm{~g}, 4.79 \mathrm{mmol}, 89 \%$ yield). $1 \mathrm{H}$ NMR (500 MHz, DMSO-d6) ס $8.13(\mathrm{~d}, \mathrm{~J}=4.0 \mathrm{~Hz}, 1 \mathrm{H}), 8.07-8.01(\mathrm{~m}, 2 \mathrm{H}), 7.51(\mathrm{~d}, \mathrm{~J}=8.2 \mathrm{~Hz}$, $2 \mathrm{H}), 6.99(\mathrm{~d}, \mathrm{~J}=4.1 \mathrm{~Hz}, 1 \mathrm{H}), 2.39(\mathrm{~s}, 4 \mathrm{H})$. HPLC (gradient A): retention time = 8.207 min; purity $=98 \%$.

2-((2-chloro-7-tosyl-7H-pyrrolo[2,3-d]pyrimidin-4-yl)amino)benzamide (S3): To a $100 \mathrm{~mL}$ round bottom flask was added 2,4-dichloro-7-tosyl-7H-pyrrolo[2,3-d]pyrimidine $\mathbf{S 2}$ (0.93 g, $2.72 \mathrm{mmol}$ ) and 2 - aminobenzamide $\mathbf{S 7}(1.48 \mathrm{~g}, 10.88 \mathrm{mmol})$. Isopropanol (16 $\mathrm{mL})$ and diisopropylethylamine $(2.38 \mathrm{~mL}, 13.6 \mathrm{mmol})$ were then added and the reaction was heated to reflux at $85{ }^{\circ} \mathrm{C}$. All solids went into solution upon heating. After refluxing overnight, the reaction was cooled down and the resulting white precipitate was filtered off and washed with additional isopropanol to give the title compound $(1.10 \mathrm{~g}, 2.49 \mathrm{mmol}, 92 \%$ yield). 1H NMR (400 MHz, DMSOd6) $\delta 12.34(\mathrm{~s}, 1 \mathrm{H}), 8.50-8.43(\mathrm{~m}, 1 \mathrm{H}), 8.32(\mathrm{~s}, 1 \mathrm{H}), 8.00(\mathrm{~d}, \mathrm{~J}=8.2 \mathrm{~Hz}, 2 \mathrm{H}), 7.85(\mathrm{~d}, \mathrm{~J}=7.9$ $\mathrm{Hz}, 1 \mathrm{H}), 7.81(\mathrm{~s}, 1 \mathrm{H}), 7.77(\mathrm{~d}, \mathrm{~J}=3.9 \mathrm{~Hz}, 1 \mathrm{H}), 7.59(\mathrm{t}, \mathrm{J}=7.9 \mathrm{~Hz}, 1 \mathrm{H}), 7.49(\mathrm{~d}, \mathrm{~J}=8.1 \mathrm{~Hz}, 2 \mathrm{H})$, $7.19(\mathrm{t}, \mathrm{J}=7.6 \mathrm{~Hz}, 1 \mathrm{H}), 6.70(\mathrm{~d}, \mathrm{~J}=4.0 \mathrm{~Hz}, 1 \mathrm{H}), 2.38(\mathrm{~s}, 3 \mathrm{H})$. HPLC (gradient A): retention time $=7.890 \mathrm{~min}$; purity $=99 \%$.

5-((4-amino-2-methoxyphenyl)amino)-3-tosylpyrrolo[2', 3':4,5]pyrimido[6,1-b]quinazolin-7(3H)one (S4): To a $100 \mathrm{~mL}$ pressure vessel was added 2-((2-chloro-7-tosyl-7H-pyrrolo[2,3d]pyrimidin-4-yl)amino)benzamide $\mathbf{S 3}(0.221 \mathrm{~g}, 0.500 \mathrm{mmol})$, (9H-fluoren-9-yl)methyl (4-amino3-methoxyphenyl)carbamate $\mathbf{S} 8(0.189 \mathrm{~g}, 0.525 \mathrm{mmol}), 4 \mathrm{M} \mathrm{HCl}$ in dioxanes $(0.50 \mathrm{~mL}, 2.0 \mathrm{mmol})$, potassium iodide $(0.01 \mathrm{~g}, 0.06 \mathrm{mmol})$, and trifluoroethanol $(10 \mathrm{~mL})$. The sealed reaction was then heated overnight at $90{ }^{\circ} \mathrm{C}$. The following day the reaction was cooled to room temperature and then a light yellow/orange solid was filtered off and taken as is to the next step.

2-((2-((4-amino-2-methoxyphenyl)amino)-7-tosyl-4,7-dihydro-3H-pyrrolo[2,3-d]pyrimidin-4yl)amino)benzamide (S5): To a $50 \mathrm{~mL}$ pressure vessel was added crude 5-((4-amino-2methoxyphenyl)amino)-3-tosylpyrrolo[2',3':4,5]pyrimido[6,1-b]quinazolin-7(3H)-one S4 (0.264 g, $0.50 \mathrm{mmol}), 28 \%$ ammonium hydroxide in water $(10 \mathrm{~mL})$, and THF $(10 \mathrm{~mL})$. The sealed reaction was heated to $60{ }^{\circ} \mathrm{C}$ overnight. After cooling the reaction was diluted with dichloromethane and water. The layers were separated, and the organic layer was washed with $\mathrm{NaCl}(2 \mathrm{x})$ and then dried over sodium sulfate. The sodium sulfate was filtered off and the filtrate was concentrated. The resulting orange solid was purified using $0-10 \% \mathrm{MeOH} / \mathrm{DCM}$ to give the title compound as a white solid $(0.120 \mathrm{~g}, 0.065 \mathrm{mmol}, 44 \%$ yield over two steps). 1H NMR (400 MHz, DMSO-d6) $\delta$ $12.12(\mathrm{~s}, 1 \mathrm{H}), 8.80(\mathrm{~s}, 1 \mathrm{H}), 8.31(\mathrm{~s}, 1 \mathrm{H}), 7.93(\mathrm{~d}, \mathrm{~J}=7.8 \mathrm{~Hz}, 2 \mathrm{H}), 7.84-7.80(\mathrm{~m}, 1 \mathrm{H}), 7.75(\mathrm{~s}$, $1 \mathrm{H}), 7.36(\mathrm{~d}, \mathrm{~J}=8.1 \mathrm{~Hz}, 3 \mathrm{H}), 7.33(\mathrm{~d}, \mathrm{~J}=4.0 \mathrm{~Hz}, 1 \mathrm{H}), 7.02(\mathrm{t}, \mathrm{J}=7.6 \mathrm{~Hz}, 1 \mathrm{H}), 6.46(\mathrm{~d}, \mathrm{~J}=4.0 \mathrm{~Hz}$, $1 \mathrm{H}), 6.38(\mathrm{~d}, \mathrm{~J}=2.2 \mathrm{~Hz}, 1 \mathrm{H}), 6.32-6.24(\mathrm{~m}, 1 \mathrm{H}), 5.02(\mathrm{~s}, 2 \mathrm{H}), 3.70(\mathrm{~s}, 3 \mathrm{H}), 2.36(\mathrm{~s}, 3 \mathrm{H})$. HPLC $($ gradient $A)$ : retention time $=5.711 \mathrm{~min}$; purity $=94 \%$.

2-((2-((4-amino-2-methoxyphenyl)amino)-4,7-dihydro-3H-pyrrolo[2, 3-d]pyrimidin-4yl)amino)benzamide (S6): To a $50 \mathrm{~mL}$ round bottom flask was added 2-((2-((4-amino-2methoxyphenyl)amino)-7-tosyl-4,7-dihydro-3H-pyrrolo[2,3-d]pyrimidin-4-yl)amino)benzamide S5 $(0.315 \mathrm{~g}, 0.579 \mathrm{mmol})$ followed by THF $(10 \mathrm{~mL}), \mathrm{MeOH}(2 \mathrm{~mL})$, and $3 \mathrm{~N}$ potassium hydroxide $(6.0 \mathrm{~mL})$. The reaction was stirred, refluxing, at $65^{\circ} \mathrm{C}$ overnight. After cooling the organic solvents 
were concentrated off and then the reaction was diluted with ethyl acetate. The layers were then separated, and the organic layer was washed with $\mathrm{NaCl}(1 \mathrm{x})$ and dried over sodium sulfate. The sodium sulfate was then filtered off and the resulting filtrate was concentrated and purified using $0 \%-8 \% \mathrm{MeOH} / \mathrm{DCM}$ to give the title compound as a slightly grey solid $(0.132 \mathrm{~g}, 0.339 \mathrm{mmol}$, $59 \%$ yield). 1H NMR (400 MHz, DMSO-d6) $\delta 11.95$ (s, 1H),

$11.19(\mathrm{~s}, 1 \mathrm{H}), 8.97(\mathrm{~d}, J=8.5 \mathrm{~Hz}, 1 \mathrm{H}), 8.28(\mathrm{~s}, 1 \mathrm{H}), 7.88-7.77(\mathrm{~m}, 1 \mathrm{H}), 7.77-7.65(\mathrm{~m}, 1 \mathrm{H})$, $7.52(\mathrm{~d}, J=8.3 \mathrm{~Hz}, 1 \mathrm{H}), 7.41(\mathrm{t}, J=7.9 \mathrm{~Hz}, 1 \mathrm{H}), 7.29(\mathrm{~s}, 1 \mathrm{H}), 6.98(\mathrm{t}, J=7.5 \mathrm{~Hz}, 1 \mathrm{H}), 6.91$ (dd, $J=3.4,2.2 \mathrm{~Hz}, 1 \mathrm{H}), 6.33(\mathrm{~d}, J=2.3 \mathrm{~Hz}, 1 \mathrm{H}), 6.22(\mathrm{dd}, J=3.5,1.9 \mathrm{~Hz}, 1 \mathrm{H}), 6.18$ (dd, $J=8.4$, $2.3 \mathrm{~Hz}, 1 \mathrm{H}), 4.91(\mathrm{~s}, 2 \mathrm{H}), 3.71(\mathrm{~s}, 3 \mathrm{H})$. HPLC (gradient $\mathrm{A})$ : retention time $=4.120$ min; purity = $84 \%$.

2-((2-((4-acrylamido-2-methoxyphenyl)amino)-7H-pyrrolo[2,3-d]pyrimidin-4-yl)amino)benzamide (5, CCG-258903)): In a $25 \mathrm{~mL}$ flask 2-((2-((4-amino-2-

methoxyphenyl)amino)-7H-pyrrolo[2,3-d]pyrimidin-4-yl)amino)benzamide S6 (0.10 g, 0.257 $\mathrm{mmol})$ was dissolved in THF $(6.0 \mathrm{~mL})$. Diisopropylethylamine $(0.134 \mathrm{~mL}, 0.770 \mathrm{mmol})$ and 1 ethyl-3-(3-dimethylaminopropyl)carbodiimide hydrochloride $(0.098 \mathrm{~g}, 0.512 \mathrm{mmol})$ were then added and the reaction was stirred ten minutes and cooled to $0{ }^{\circ} \mathrm{C}$. Acrylic acid $(0.02 \mathrm{~mL}, 0.282$ $\mathrm{mmol}$ ) was then added and the reaction was allowed to warm to room temperature and stir overnight. Water was added to quench the reaction and then ethyl acetate was added to extract the organics. The layers were separated, and the organic layer was washed with $\mathrm{NaHCO}_{3}(1 \mathrm{x})$, dried over magnesium sulfate, and concentrated. The resulting residue was purified using flash chromatography $(0-10 \% \mathrm{MeOH} / \mathrm{DCM})$ to give a light yellow solid as the desired compound (0.0107 g, $0.024 \mathrm{mmol}, 10 \%$ yield). 1H NMR (400 MHz, DMSO-d6) $\delta 11.99$ (s, 1H), 11.36 (s, $1 \mathrm{H}), 10.10(\mathrm{~s}, 1 \mathrm{H}), 8.93(\mathrm{~d}, J=8.5 \mathrm{~Hz}, 1 \mathrm{H}), 8.30(\mathrm{~s}, 1 \mathrm{H}), 8.20(\mathrm{~d}, J=8.7 \mathrm{~Hz}, 1 \mathrm{H}), 7.83(\mathrm{~d}, J=$ $7.7 \mathrm{~Hz}, 1 \mathrm{H}), 7.74(\mathrm{~s}, 1 \mathrm{H}), 7.56-7.43(\mathrm{~m}, 3 \mathrm{H}), 7.24-7.16(\mathrm{~m}, 1 \mathrm{H}), 7.07-6.97(\mathrm{~m}, 2 \mathrm{H}), 6.44$ (dd, $J=17.0,10.1 \mathrm{~Hz}, 1 \mathrm{H}), 6.32-6.20(\mathrm{~m}, 2 \mathrm{H}), 5.78-5.70(\mathrm{~m}, 1 \mathrm{H}), 3.85(\mathrm{~s}, 3 \mathrm{H})$. HPLC (gradient $A$ ): retention time $=4.987$ min; purity $=95 \%$. Molecular formula: $\mathrm{C}_{23} \mathrm{H}_{21} \mathrm{~N}_{7} \mathrm{O}_{3}$, Mass Calc: 443.17, ESI-MS Found: 444.1626 [M+1]

(E)-2-((2-((4-(4-(dimethylamino)but-2-enamido)-2-methoxyphenyl)amino)-7H-pyrrolo[2,3d]pyrimidin-4-yl)amino)benzamide (6, CCG-263045): In a $25 \mathrm{~mL}$ flask 2-((2-((4amino-2-methoxyphenyl)amino)-7H-pyrrolo[2,3-d]pyrimidin-4-yl)amino)benzamide $\mathbf{S 6}$ (0.137 $\mathrm{g}, 0.352 \mathrm{mmol})$ was dissolved in THF $(6.0 \mathrm{~mL})$. Diisopropylethylamine $(0.246 \mathrm{~mL}, 0.1 .41$ $\mathrm{mmol})$ and 1-ethyl-3-(3-dimethylaminopropyl)carbodiimide hydrochloride $(0.108 \mathrm{~g}, 0.563$ $\mathrm{mmol}$ ) were then added and the reaction was stirred ten minutes and cooled to $0{ }^{\circ} \mathrm{C}$. Trans-4dimethylaminocrotonic acid hydrochloride $(0.070 \mathrm{~g}, 0.422 \mathrm{mmol})$ was then added and the reaction was allowed to warm to room temperature and stir overnight. Water was added to quench the reaction and then ethyl acetate was added to extract the organics. The layers were separated, and the organic layer was washed with $\mathrm{NaCl}(1 \mathrm{x})$, dried over magnesium sulfate, and concentrated. The resulting residue was purified using flash chromatography $(5-10 \%$ $\mathrm{MeOH} / \mathrm{DCM})$ to give a light brown solid as the desired compound $(0.017 \mathrm{~g}, 0.034 \mathrm{mmol}, 10 \%$ yield). 1H NMR (400 MHz, DMSO-d6) $\delta 11.99(\mathrm{~s}, 1 \mathrm{H}), 11.36$ (s, 1H), 10.02 (s, 1H), 8.94 (dd, $J=$ $8.4,1.2 \mathrm{~Hz}, 1 \mathrm{H}), 8.30(\mathrm{~s}, 1 \mathrm{H}), 8.17(\mathrm{~d}, J=8.7 \mathrm{~Hz}, 1 \mathrm{H}), 7.83(\mathrm{dd}, J=8.1,1.6 \mathrm{~Hz}, 1 \mathrm{H}), 7.75(\mathrm{~s}, 1 \mathrm{H})$, $7.56-7.42(\mathrm{~m}, 3 \mathrm{H}), 7.17(\mathrm{dd}, J=8.7,2.1 \mathrm{~Hz}, 1 \mathrm{H}), 7.07-6.96(\mathrm{~m}, 2 \mathrm{H}), 6.72(\mathrm{dt}, J=15.4,5.9 \mathrm{~Hz}$, $1 \mathrm{H}), 6.31-6.24(\mathrm{~m}, 2 \mathrm{H}), 3.84(\mathrm{~s}, 3 \mathrm{H}), 3.10-3.03(\mathrm{~m}, 2 \mathrm{H}), 2.19(\mathrm{~s}, 6 \mathrm{H})$. HPLC (gradient A): retention time $=4.305$ min; purity $=97 \%$. Molecular Formula: $\mathrm{C}_{26} \mathrm{H}_{28} \mathrm{~N}_{8} \mathrm{O}_{3}$, Mass Calc: 500.23 , ESI-MS Found: $501.2343[\mathrm{M}+1]$ 

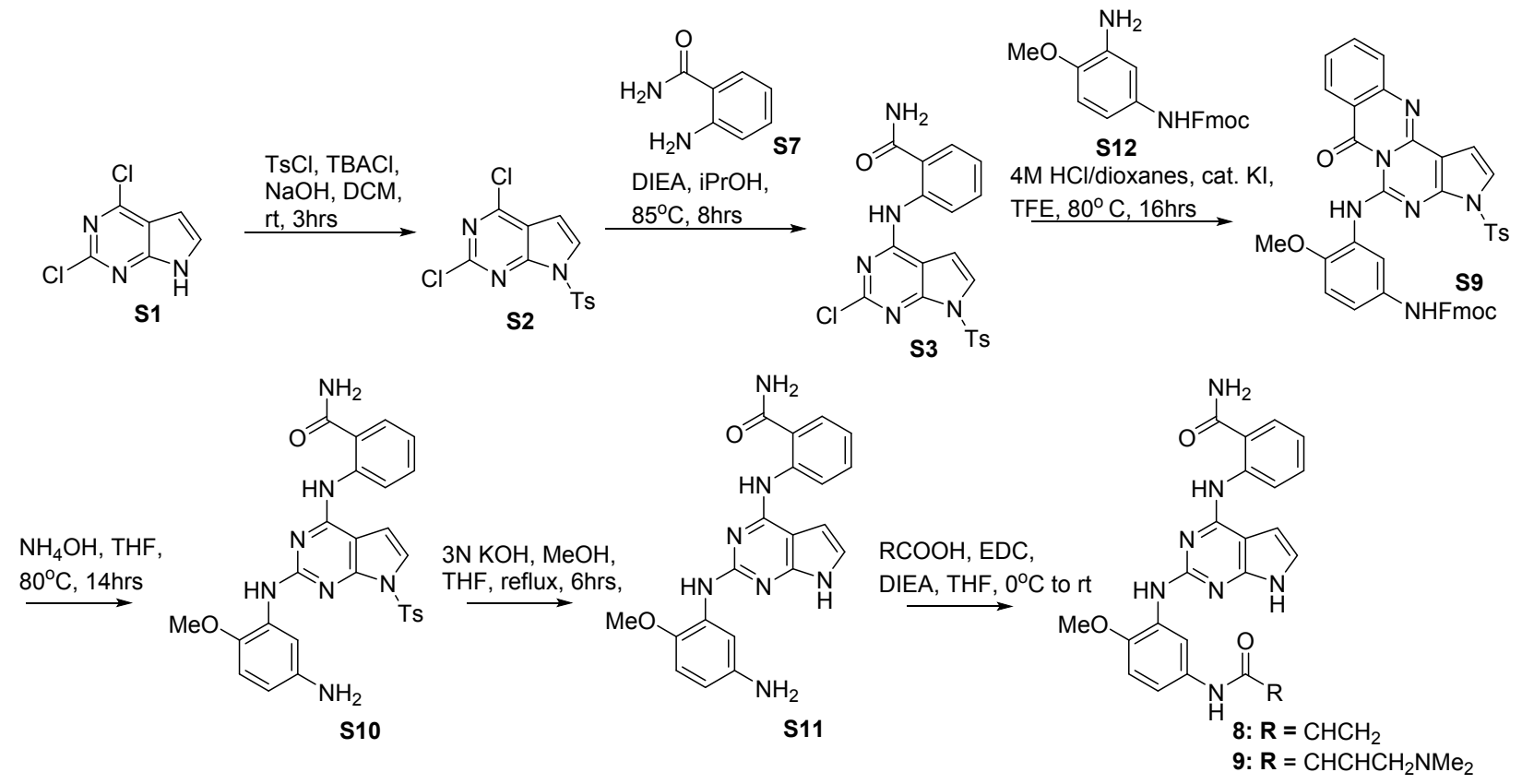

Scheme S2: Synthesis of non-homologated meta-substituted analogues.

(9H-fluoren-9-yl)methyl (4-methoxy-3-((7-oxo-3-tosyl-3,7-dihydropyrrolo[2', 3':4, 5]pyrimido[6, 1b]quinazolin-5-yl)amino)phenyl)carbamate (S9): To a $100 \mathrm{~mL}$ pressure vessel was added 2-((2chloro-7-tosyl-7 H-pyrrolo[2,3-d]pyrimidin-4-yl)amino)benzamide $\mathbf{S 3}(0.60 \mathrm{~g}, 1.36 \mathrm{mmol}),(9 \mathrm{H}-$ fluoren-9-yl)methyl (3-amino-4-methoxyphenyl)carbamate $\mathbf{S} 12(0.515 \mathrm{~g}, 1.43 \mathrm{mmol}), 4 \mathrm{M} \mathrm{HCl}$ in dioxanes $(1.36 \mathrm{~mL}, 5.44 \mathrm{mmol})$, potassium iodide $(0.04 \mathrm{~g}, 0.24 \mathrm{mmol})$, and trifluoroethanol (40 $\mathrm{mL}$ ). The sealed reaction was then heated overnight at $90{ }^{\circ} \mathrm{C}$. The following day the reaction was cooled to room temperature and then diluted with water and an excessive amount of dichloromethane $(\sim 100 \mathrm{~mL}$, otherwise an emulsion will form). The layers were separated and the organic was washed with $\mathrm{NaCl}(1 \mathrm{x})$ and dried with sodium sulfate. The sodium sulfate was then filtered off and the filtrate was concentrated to give a light yellow/orange solid which was taken as is to the next step.

(9H-fluoren-9-yl)methyl (4-methoxy-3-((7-oxo-3-tosyl-3,7-dihydropyrrolo[2', 3':4,5]pyrimido[6,1b]quinazolin-5-yl)amino)phenyl)carbamate (S10): To a $100 \mathrm{~mL}$ pressure vessel was added $(9 \mathrm{H}-$ fluoren-9-yl)methyl (4-methoxy-3-((7-oxo-3-tosyl-3,7-dihydropyrrolo[2',3':4,5]pyrimido[6,1b]quinazolin-5-yl)amino)phenyl)carbamate $\mathbf{S 9}(1.02 \mathrm{~g}, 1.36 \mathrm{mmol}), 28 \%$ ammonium hydroxide in water $(20 \mathrm{~mL})$, and THF $(20 \mathrm{~mL})$. The reaction was heated in a sealed pressure vessel to $60{ }^{\circ} \mathrm{C}$ overnight. After cooling the reaction was diluted with ethyl acetate and water. The layers were separated, and the organic layer was washed with $\mathrm{NaCl}(2 \mathrm{x})$ and then dried of sodium sulfate. The sodium sulfate was filtered off and the filtrate was concentrated. The resulting orange solid was triturated in dichloromethane to give the title compound as an off white solid $(0.378 \mathrm{~g}, 0.70$ mmol, $51 \%$ yield over two steps). $1 \mathrm{H}$ NMR $(400 \mathrm{MHz}$, DMSO-d6) $\delta 12.13(\mathrm{~s}, 1 \mathrm{H}), 8.76$ (dd, $\mathrm{J}=$ 8.5, $1.1 \mathrm{~Hz}, 1 \mathrm{H}), 8.31(\mathrm{~s}, 1 \mathrm{H}), 8.03-7.97(\mathrm{~m}, 2 \mathrm{H}), 7.93(\mathrm{~s}, 1 \mathrm{H}), 7.83(\mathrm{dd}, \mathrm{J}=8.0,1.5 \mathrm{~Hz}, 1 \mathrm{H})$, $7.76(\mathrm{~s}, 1 \mathrm{H}), 7.49$ (ddd, J = 8.6, 5.7, $1.5 \mathrm{~Hz}, 2 \mathrm{H}), 7.41(\mathrm{~d}, \mathrm{~J}=4.0 \mathrm{~Hz}, 1 \mathrm{H}), 7.38(\mathrm{~d}, \mathrm{~J}=8.2 \mathrm{~Hz}, 2 \mathrm{H})$, $7.09-7.02(\mathrm{~m}, 1 \mathrm{H}), 6.81(\mathrm{~d}, \mathrm{~J}=8.6 \mathrm{~Hz}, 1 \mathrm{H}), 6.53(\mathrm{~d}, \mathrm{~J}=4.0 \mathrm{~Hz}, 1 \mathrm{H}), 6.37$ (dd, J = 8.5, $2.7 \mathrm{~Hz}$, $1 \mathrm{H}), 4.55(\mathrm{~s}, 2 \mathrm{H}), 3.72(\mathrm{~s}, 3 \mathrm{H}), 2.34(\mathrm{~s}, 3 \mathrm{H})$. HPLC (gradient A): retention time $=5.850$ min; purity $=88 \%$. 
2-((2-((5-amino-2-methoxyphenyl)amino)-4,7-dihydro-3H-pyrrolo[2,3-d]pyrimidin-4yl)amino)benzamide (S11): To a $25 \mathrm{~mL}$ round bottom flask was added (9H-fluoren-9-yl)methyl (4methoxy-3-((7-oxo-3-tosyl-3,7-dihydropyrrolo[2',3':4,5]pyrimido[6,1-b]quinazolin-5-

$\mathrm{yl}$ )amino)phenyl)carbamate $\mathbf{S 1 0}(0.158 \mathrm{~g}, 0.291 \mathrm{mmol})$, methanol $(2 \mathrm{~mL}), 3 \mathrm{~N}$ potassium hydroxide $(2 \mathrm{~mL})$ and THF $(4.5 \mathrm{~mL})$. The reaction was heated to $65^{\circ} \mathrm{C}$ and stirred overnight for two days. The reaction was then cooled, and the organic layers were concentrated off. The resulting suspension in the aqueous layer was then filtered off to give adequately pure compound (0.082 mg, 72\% yield). 1H NMR (500 MHz, DMSO-d6) $\delta 11.99$ (s, 1H), 11.33 (s, 1H), 8.97 (d, J $=8.1 \mathrm{~Hz}, 1 \mathrm{H}), 8.28(\mathrm{~s}, 1 \mathrm{H}), 7.83(\mathrm{dd}, \mathrm{J}=8.0,1.5 \mathrm{~Hz}, 1 \mathrm{H}), 7.72(\mathrm{~s}, 1 \mathrm{H}), 7.59-7.49(\mathrm{~m}, 2 \mathrm{H}), 7.39$ $(\mathrm{s}, 1 \mathrm{H}), 7.06-6.97(\mathrm{~m}, 2 \mathrm{H}), 6.73(\mathrm{~d}, \mathrm{~J}=8.6 \mathrm{~Hz}, 1 \mathrm{H}), 6.29(\mathrm{dd}, \mathrm{J}=3.5,1.9 \mathrm{~Hz}, 1 \mathrm{H}), 6.21(\mathrm{dd}, \mathrm{J}=$ 8.5, $2.7 \mathrm{~Hz}, 1 \mathrm{H}), 4.47(\mathrm{~s}, 2 \mathrm{H}), 3.74(\mathrm{~s}, 3 \mathrm{H})$. HPLC (gradient A): retention time $=4.166$ min; purity $=91 \%$.

2-((2-((5-acrylamido-2-methoxyphenyl)amino)-7H-pyrrolo[2,3-d]pyrimidin-4-yl)amino)benzamide (8, CCG-258904): In a $25 \mathrm{~mL}$ flask 2-((2-((5-amino-2-methoxyphenyl)amino)-7H-pyrrolo[2,3d]pyrimidin-4-yl)amino)benzamide $\mathbf{S} 11(0.088 \mathrm{~g}, 0.226 \mathrm{mmol})$ was dissolved in THF $(6.0 \mathrm{~mL})$. Diisopropylethylamine $(0.12 \mathrm{~mL}, 0.678 \mathrm{mmol})$ and 1-Ethyl-3-(3 dimethylaminopropyl)carbodiimide hydrochloride $(0.087 \mathrm{~g}, 0.452 \mathrm{mmol})$ were then added and the reaction was stirred ten minutes and cooled to $0{ }^{\circ} \mathrm{C}$. Acrylic acid $(0.017 \mathrm{~mL}, 0.249 \mathrm{mmol})$ was then added and the reaction was allowed to warm to room temperature and stir overnight. Water was added to quench the reaction and then ethyl acetate was added to extract the organics. The layers were separated, and the organic layer was washed with $\mathrm{NaCO} 3(1 \mathrm{x})$, dried over magnesium sulfate, and concentrated. The resulting residue was subjected to flash chromatography $(5-10 \% \mathrm{MeOH} / \mathrm{DCM})$ and then purified using reverse phase chromatography ( $30-60 \%$ Acetonitrile/Water) to give the desired compound as a light yellow solid $(0.012 \mathrm{~g}, 0.026 \mathrm{mmol}, 12 \%$ yield). $1 \mathrm{H} \mathrm{NMR}(500 \mathrm{MHz}$, DMSOd6) $\delta 12.05(\mathrm{~s}, 1 \mathrm{H}), 11.44(\mathrm{~s}, 1 \mathrm{H}), 10.05(\mathrm{~s}, 1 \mathrm{H}), 8.94(\mathrm{~d}, \mathrm{~J}=8.4 \mathrm{~Hz}, 1 \mathrm{H}), 8.28(\mathrm{~d}, \mathrm{~J}=2.8 \mathrm{~Hz}, 2 \mathrm{H})$, $7.82(\mathrm{dd}, \mathrm{J}=7.9,1.6 \mathrm{~Hz}, 1 \mathrm{H}), 7.73(\mathrm{~s}, 1 \mathrm{H}), 7.59(\mathrm{~s}, 1 \mathrm{H}), 7.44-7.36(\mathrm{~m}, 2 \mathrm{H}), 6.98(\mathrm{q}, \mathrm{J}=7.1,5.9$ $\mathrm{Hz}, 3 \mathrm{H}), 6.45$ (dd, J = 17.0, $10.2 \mathrm{~Hz}, 1 \mathrm{H}), 6.29(\mathrm{~d}, \mathrm{~J}=3.5 \mathrm{~Hz}, 1 \mathrm{H}), 6.22(\mathrm{dd}, \mathrm{J}=17.0,2.1 \mathrm{~Hz}, 1 \mathrm{H}$ ), $5.71(\mathrm{dd}, \mathrm{J}=10.0,2.1 \mathrm{~Hz}, 1 \mathrm{H}), 3.84(\mathrm{~s}, 3 \mathrm{H})$. HPLC (gradient A): retention time $=4.921$ min; purity $=93 \%$. Molecular Formula: $\mathrm{C}_{23} \mathrm{H}_{21} \mathrm{~N}_{7} \mathrm{O}_{3}$, Mass Calc: 443.17, ESI-MS Found: $444.1630[\mathrm{M}+1]$.

(E)-2-((2-((4-(4-(dimethylamino)but-2-enamido)-2-methoxyphenyl)amino)-7H-pyrrolo[2,3-

d]pyrimidin-4-yl)amino)benzamide (9, CCG-263115): In a $25 \mathrm{~mL}$ flask 2-((2-((5-amino-2methoxyphenyl)amino)-7H-pyrrolo[2,3-d]pyrimidin-4-yl)amino)benzamide S11 (0.073 g, 0.187 $\mathrm{mmol})$ was dissolved in THF $(4.0 \mathrm{~mL})$. Diisopropylethylamine $(0.10 \mathrm{~mL}, 0.561 \mathrm{mmol})$ and 1-Ethyl3-(3-dimethylaminopropyl)carbodiimide hydrochloride $(0.047 \mathrm{~g}, 0.243 \mathrm{mmol})$ were then added and the reaction was stirred ten minutes and cooled to $0{ }^{\circ} \mathrm{C}$. Trans-4-dimethylaminocrotonic acid hydrochloride $(0.034 \mathrm{~g}, 0.206 \mathrm{mmol})$ was then added and the reaction was allowed to warm to room temperature and stir three hours. Water was added to quench the reaction and then ethyl acetate was added to extract the organics. The layers were separated, and the organic layer was washed with $\mathrm{NaCl}(1 \mathrm{x})$, dried over magnesium sulfate, and concentrated. The resulting residue was purified using flash chromatography $(5-10 \% \mathrm{MeOH} / \mathrm{DCM})$ to give a light brown solid as the desired compound $(0.012 \mathrm{~g}, 0.024 \mathrm{mmol}, 13 \%$ yield). $1 \mathrm{H} \mathrm{NMR}(500 \mathrm{MHz}$, DMSO-d6) $\delta 12.07$ (s, $1 \mathrm{H}), 11.34(\mathrm{~s}, 1 \mathrm{H}), 9.88(\mathrm{~s}, 1 \mathrm{H}), 8.94(\mathrm{dd}, \mathrm{J}=8.6,1.2 \mathrm{~Hz}, 1 \mathrm{H}), 8.30(\mathrm{~s}, 1 \mathrm{H}), 8.24(\mathrm{~d}, \mathrm{~J}=2.5 \mathrm{~Hz}$, $1 \mathrm{H}), 7.82(\mathrm{dd}, \mathrm{J}=7.9,1.6 \mathrm{~Hz}, 1 \mathrm{H}), 7.74(\mathrm{~s}, 1 \mathrm{H}), 7.60(\mathrm{~s}, 1 \mathrm{H}), 7.43-7.34(\mathrm{~m}, 2 \mathrm{H}), 7.05-6.94(\mathrm{~m}$, $3 \mathrm{H}), 6.75-6.65(\mathrm{~m}, 1 \mathrm{H}), 6.30-6.22(\mathrm{~m}, 2 \mathrm{H}), 3.83(\mathrm{~s}, 3 \mathrm{H}), 3.04(\mathrm{dd}, \mathrm{J}=6.1,1.6 \mathrm{~Hz}, 2 \mathrm{H}), 2.18$ $(\mathrm{s}, 6 \mathrm{H}$ ). HPLC (gradient A): retention time $=4.353 \mathrm{~min}$; purity $=93 \%$. Molecular Formula: $\mathrm{C}_{26} \mathrm{H}_{28} \mathrm{~N}_{8} \mathrm{O}_{3}$, Mass Calc: 500.23, ESI-MS Found: 501.2356 [M+1] 


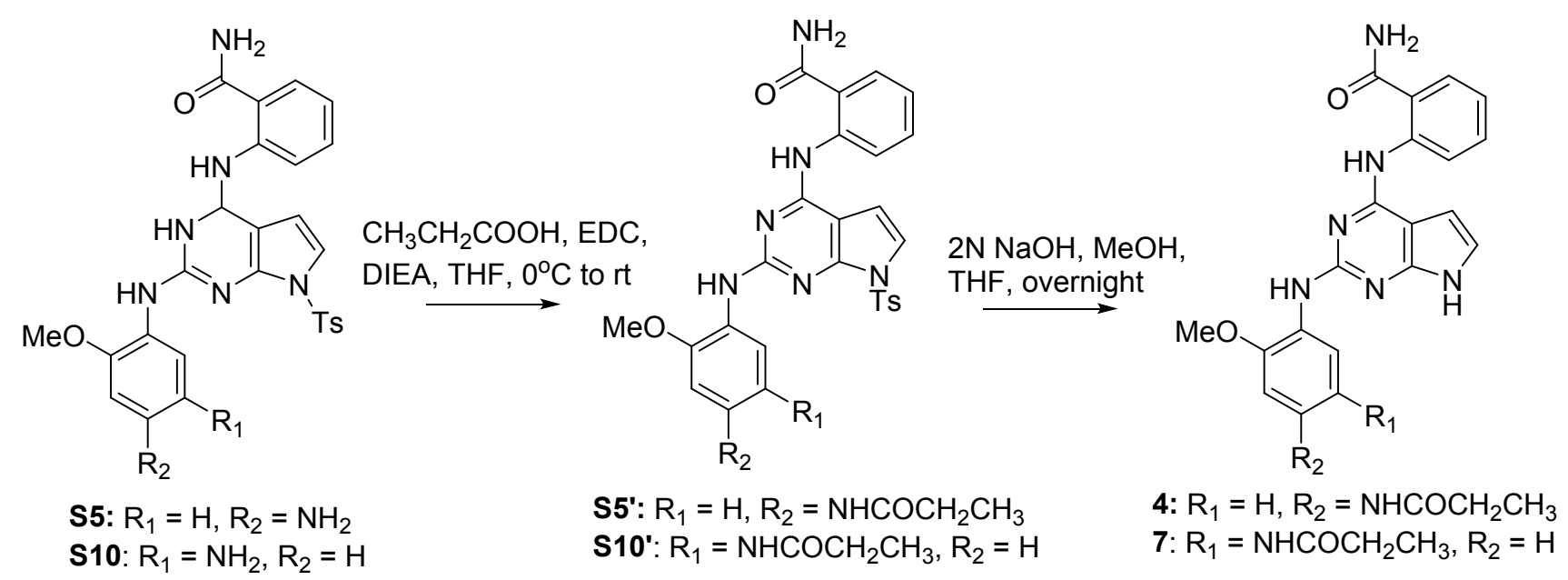

Synthesis of saturated analogs 4 and 7 .

2-((2-((2-methoxy-4-propionamidophenyl)amino)-7-tosyl-7H-pyrrolo[2,3-d]pyrimidin-4yl)amino)benzamide (S5'): To a $25 \mathrm{~mL}$ round bottom flask was added 2-((2-((4-amino-2methoxyphenyl)amino)-7-tosyl-4,7-dihydro-3H-pyrrolo[2,3-d]pyrimidin-4-yl)amino)benzamide S5 $(0.070 \mathrm{~g}, 0.128 \mathrm{mmol}), 1$-Ethyl-3-(3-dimethylaminopropyl)carbodiimide hydrochloride (0.049 $\mathrm{g}, 0.258 \mathrm{mmol})$, diisopropylethylamine $(0.068 \mathrm{~mL}, 0.387 \mathrm{mmol})$, and THF $(4.0 \mathrm{~mL})$. The reaction was cooled to $0{ }^{\circ} \mathrm{C}$ and then stirred for ten minutes before adding propionic acid $(0.012 \mathrm{~mL}$, $0.155 \mathrm{mmol}$ ). The reaction was further stirred overnight. Water was added to quench the reaction and then the reaction was further diluted with ethyl acetate. The two layers were separated. The organic layer was washed with $10 \%$ citric acid (1x), $\mathrm{NaCl}(2 \mathrm{x})$, and then dried with sodium sulfate. The sodium sulfate was then filtered off and the filtrate was concentrated. The resulting residue was purified using $0-5 \%$ methanol/dichloromethane to give the title compound as a light pink solid $(0.022 \mathrm{~g}, 0.041 \mathrm{mmol}, 32 \%$ yield $) .{ }^{1} \mathrm{H}$ NMR $\left(400 \mathrm{MHz}\right.$, DMSO- $\left.d_{6}\right)$ $\delta 12.12(\mathrm{~s}, 1 \mathrm{H}), 9.88(\mathrm{~s}, 1 \mathrm{H}), 8.75(\mathrm{~d}, J=8.4 \mathrm{~Hz}, 1 \mathrm{H}), 8.31(\mathrm{~s}, 1 \mathrm{H}), 8.04(\mathrm{~s}, 1 \mathrm{H}), 7.94(\mathrm{~d}, J=8.1$ $\mathrm{Hz}, 3 \mathrm{H}), 7.82(\mathrm{dd}, J=8.0,1.6 \mathrm{~Hz}, 1 \mathrm{H}), 7.76(\mathrm{~s}, 1 \mathrm{H}), 7.50(\mathrm{~d}, J=2.1 \mathrm{~Hz}, 1 \mathrm{H}), 7.48-7.34(\mathrm{~m}$, 4H), $7.20(\mathrm{dd}, J=8.6,2.1 \mathrm{~Hz}, 1 \mathrm{H}), 7.10-7.02(\mathrm{~m}, 1 \mathrm{H}), 6.52(\mathrm{~d}, J=4.0 \mathrm{~Hz}, 1 \mathrm{H}), 3.81(\mathrm{~s}, 3 \mathrm{H})$, $2.41-2.30(\mathrm{~m}, 5 \mathrm{H}), 1.12(\mathrm{t}, J=7.6 \mathrm{~Hz}, 3 \mathrm{H})$. HPLC (gradient A): retention time = $7.312 \mathrm{~min}$; purity $=94 \%$.

2-((2-((2-methoxy-5-propionamidophenyl)amino)-7-tosyl-7H-pyrrolo[2,3-d]pyrimidin-4yl)amino)benzamide (S10'): To a $25 \mathrm{~mL}$ round bottom flask was added (9H-fluoren-9-yl)methyl (4-methoxy-3-((7-oxo-3-tosyl-3,7-dihydropyrrolo[2',3':4,5]pyrimido[6,1-b]quinazolin-5yl)amino)phenyl)carbamate $\mathbf{S 1 0}(0.100 \mathrm{~g}, 0.184 \mathrm{mmol}), 1$-Ethyl-3-(3dimethylaminopropyl)carbodiimide hydrochloride $(0.071 \mathrm{~g}, 0.368 \mathrm{mmol})$, diisopropylethylamine $(0.096 \mathrm{~mL}, 0.552 \mathrm{mmol})$, and THF $(4.0 \mathrm{~mL})$. The reaction was cooled to $0{ }^{\circ} \mathrm{C}$ and then stirred for ten minutes before adding propionic acid $(0.017 \mathrm{~mL}, 0.221 \mathrm{mmol})$. The reaction was further stirred overnight. Water was added to quench the reaction and then the reaction was further diluted with ethyl acetate. The two layers were separated. The organic layer was washed with $10 \%$ citric acid (1x), $\mathrm{NaCl}(2 \mathrm{x})$, and then dried with sodium sulfate. The sodium sulfate was then filtered off and the filtrate was concentrated. The resulting residue was purified using $0-5 \%$ isopropanol/dichloromethane to give the title compound as a white solid $(0.065 \mathrm{~g}, 0.108 \mathrm{mmol}$, $59 \%$ yield). ${ }^{1} \mathrm{H}$ NMR (400 MHz, DMSO-d 6 ) $\delta 12.20(\mathrm{~s}, 1 \mathrm{H}), 9.71(\mathrm{~s}, 1 \mathrm{H}), 8.71(\mathrm{~d}, \mathrm{~J}=8.4 \mathrm{~Hz}, 1 \mathrm{H})$, $8.32(\mathrm{~s}, 1 \mathrm{H}), 8.26(\mathrm{~s}, 1 \mathrm{H}), 7.97(\mathrm{~d}, J=8.2 \mathrm{~Hz}, 2 \mathrm{H}), 7.93(\mathrm{~d}, J=2.5 \mathrm{~Hz}, 1 \mathrm{H}), 7.82$ (dd, $J=8.0$, 
$1.5 \mathrm{~Hz}, 1 \mathrm{H}), 7.77(\mathrm{~s}, 1 \mathrm{H}), 7.39(\mathrm{~d}, J=4.0 \mathrm{~Hz}, 1 \mathrm{H}), 7.38-7.28(\mathrm{~m}, 4 \mathrm{H}), 7.07-6.99(\mathrm{~m}, 2 \mathrm{H})$, $6.50(\mathrm{~d}, J=4.0 \mathrm{~Hz}, 1 \mathrm{H}), 3.79(\mathrm{~s}, 3 \mathrm{H}), 2.34(\mathrm{~s}, 3 \mathrm{H}), 2.29(\mathrm{q}, J=7.6 \mathrm{~Hz}, 2 \mathrm{H}), 1.07$ (t, J = $7.6 \mathrm{~Hz}$, $3 \mathrm{H}$ ). HPLC (gradient $A$ ): retention time $=7.195$ min; purity $=93 \%$.

2-((2-((2-methoxy-4-propionamidophenyl)amino)-7H-pyrrolo[2,3-d]pyrimidin-4yl)amino)benzamide (4, CCG-262604): In a $25 \mathrm{~mL}$ round bottom flask a suspension of 2-((2-((2-methoxy-4-propionamidophenyl)amino)-7-tosyl-7H-pyrrolo[2,3-d]pyrimidin-4yl)amino)benzamide $(0.022 \mathrm{~g}, 0.037 \mathrm{mmol}), \mathrm{MeOH}(1.0 \mathrm{~mL}), \mathrm{THF}(4.0 \mathrm{~mL})$, and $2 \mathrm{~N} \mathrm{NaOH}$ $(4.0 \mathrm{~mL})$ was stirred overnight becoming clearer. The reaction was diluted with ethyl acetate and water. The layers were separated and the organic was washed with $\mathrm{NaCl}(1 \mathrm{x})$, dried over $\mathrm{MgSO} 4$, and concentrated. The resulting crude residue was purified using $5 \%-10 \% \mathrm{MeOH} / \mathrm{DCM}$ and then further purified by recrystallizing from 15\% MeOH/DCM overnight $(\sim 1.5 \mathrm{~mL})$ to give the title compound as an off white solid $(0.013 \mathrm{~g}, 0.029 \mathrm{mmol}, 78 \%$ yield). 1H NMR (400 MHz,DMSO-d6) $\delta 11.99(\mathrm{~s}, 1 \mathrm{H}), 11.34(\mathrm{~s}, 1 \mathrm{H}), 9.79(\mathrm{~s}, 1 \mathrm{H}), 8.93(\mathrm{~d}, J=8.5 \mathrm{~Hz}, 1 \mathrm{H}), 8.30(\mathrm{~s}, 1 \mathrm{H}), 8.13(\mathrm{~d}, J=8.6$ $\mathrm{Hz}, 1 \mathrm{H}), 7.83(\mathrm{~d}, J=8.0 \mathrm{~Hz}, 1 \mathrm{H}), 7.75(\mathrm{~s}, 1 \mathrm{H}), 7.53-7.40(\mathrm{~m}, 3 \mathrm{H}), 7.10(\mathrm{~d}, J=8.7 \mathrm{~Hz}, 1 \mathrm{H}), 7.05$ - $6.95(\mathrm{~m}, 2 \mathrm{H}), 6.28(\mathrm{~s}, 1 \mathrm{H}), 3.82(\mathrm{~s}, 3 \mathrm{H}), 2.31(\mathrm{q}, J=8.5,7.5 \mathrm{~Hz}, 2 \mathrm{H}), 1.09(\mathrm{t}, J=7.5 \mathrm{~Hz}, 3 \mathrm{H})$. HPLC (gradient A): retention time $=4.906$ min; purity $=95 \%$. Molecular Formula: $\mathrm{C}_{23} \mathrm{H}_{23} \mathrm{~N}_{7} \mathrm{O}_{3}$, Mass Calc: 445.19, ESI-MS Found: 446.1926 [M+1]

2-((2-((2-methoxy-5-propionamidophenyl)amino)-7H-pyrrolo[2,3-d]pyrimidin-4yl)amino)benzamide (7, CCG-262606): In a $25 \mathrm{~mL}$ flask 2-((2-((2-methoxy-5propionamidophenyl)amino)-7-tosyl-7H-pyrrolo[2,3-d]pyrimidin-4-yl)amino)benzamide 128 $(0.062 \mathrm{~g}, 0.104 \mathrm{mmol})$ was suspended in 1,4 - dioxanes $(5.0 \mathrm{~mL})$ and $2 \mathrm{~N} \mathrm{NaOH}(5.0 \mathrm{~mL})$ and the reaction was stirred vigorously. After 2 hours the reaction was still cloudy and THF $(3 \mathrm{~mL})$ and $\mathrm{MeOH}(1 \mathrm{~mL})$ were then added and the reaction was stirred overnight. The organics were then concentrated off and the $\mathrm{pH}$ was lowered with concentrated $\mathrm{HCl}$ at which point a new side product formed. Assuming it was the cyclized lactam the compound was then stirred in a sealed reaction vessel with $28 \% \mathrm{NH} 4 \mathrm{OH}(4 \mathrm{~mL})$ and THF $(4 \mathrm{~mL})$ at $40{ }^{\circ} \mathrm{C}$ for four hours, concentrated, and extracted with ethyl acetate (disappearance of the side product was observed confirming likelihood of it being the cyclized lactam). The organic was then washed with $\mathrm{NaCl}(1 \mathrm{x})$, dried over $\mathrm{MgSO} 4$, and concentrated. The resulting residue was then purified on flash chromatography using a gradient of $0-5 \% \mathrm{MeOH} / \mathrm{DCM}$ to afford the desired product as a pale yellow solid $(0.036 \mathrm{mg}$, $0.081 \mathrm{mmol}, 78 \%$ yield). 1H NMR (400 MHz, DMSO-d6) $\delta 12.07(\mathrm{~s}, 1 \mathrm{H}), 11.33(\mathrm{~s}, 1 \mathrm{H}), 9.65$ (s, $1 \mathrm{H}), 8.97-8.90(\mathrm{~m}, 1 \mathrm{H}), 8.30(\mathrm{~s}, 1 \mathrm{H}), 8.15(\mathrm{~d}, \mathrm{~J}=2.5 \mathrm{~Hz}, 1 \mathrm{H}), 7.83(\mathrm{~d}, \mathrm{~J}=7.9 \mathrm{~Hz}, 1 \mathrm{H}), 7.75(\mathrm{~s}$, 1H), $7.58(\mathrm{~s}, 1 \mathrm{H}), 7.39(\mathrm{t}, \mathrm{J}=7.8 \mathrm{~Hz}, 1 \mathrm{H}), 7.30(\mathrm{dd}, \mathrm{J}=8.8,2.5 \mathrm{~Hz}, 1 \mathrm{H}), 7.04-6.92(\mathrm{~m}, 3 \mathrm{H}), 6.29$ (dd, J = 3.5, $1.9 \mathrm{~Hz}, 1 \mathrm{H}), 3.82(\mathrm{~s}, 3 \mathrm{H}), 2.27(\mathrm{q}, \mathrm{J}=7.6 \mathrm{~Hz}, 2 \mathrm{H}), 1.07$ (t, J =7.6 Hz, 3H). HPLC (gradient A): retention time $=4.927$ min; purity $=95 \%$ Molecular Formula: $\mathrm{C}_{23} \mathrm{H}_{23} \mathrm{~N}_{7} \mathrm{O}_{3}$, Mass Calc: 445.19, ESI-MS Found: 446.1938 [M+1] 
<smiles>CNC(=O)c1ccccc1Nc1nc(Cl)nc2c1ccn2C=S</smiles>

2-((2-Chloro-7-((2-(trimethylsilyl)ethoxy)methyl)-7H-pyrrolo[2, 3-d]pyrimidin-4-yl)amino)-Nmethylbenzamide (12)

A flask was charged with $1.000 \mathrm{~g}$ of 11 (3 mmol, 1 equiv.), $501.1 \mathrm{mg}$ of 2-amino-Nmethylbenzamide ( $3 \mathrm{mmol}, 1$ equiv.), and $16 \mathrm{~mL}$ of THF. The resulting solution was cooled to 0 ${ }^{\circ} \mathrm{C}$ and $702.1 \mathrm{mg}$ of KOtBu (6.0 mmol, 2 equiv.) were added to form an orange solution which was heated to $120{ }^{\circ} \mathrm{C}$ for $3 \mathrm{~h}$. The solution was cooled to rt and quenched with water, extracted with EtOAc $(3 \times 100 \mathrm{~mL})$ and the combined organic layers were washed with brine $(1 \times 50 \mathrm{~mL})$. The organic layer was dried over $\mathrm{Na}_{2} \mathrm{SO}_{4}$, filtered and concentrated in vacuo and purified by column chromatography eluting with $60 \%$ EtOAc/Hexanes to afford an off white solid. Yield: $802.0 \mathrm{mg}$, $60 \%$ HPLC: 8.96 min, Molecular Formula: $\mathrm{C}_{20} \mathrm{H}_{26} \mathrm{CIN}_{5} \mathrm{O}_{2} \mathrm{Si}$, Mass Calc: 431.15, ESI-MS-Found: 432 [M+1], purity: 92\% ${ }^{1} \mathrm{HNMR}(500 \mathrm{MHz}, \mathrm{DMSO}-\mathrm{d} 6) \delta 12.06(\mathrm{~s}, 1 \mathrm{H}), 8.80(\mathrm{~d}, \mathrm{~J}=5.0 \mathrm{~Hz}, 1 \mathrm{H})$, $8.63(\mathrm{~d}, \mathrm{~J}=8.4 \mathrm{~Hz}, 1 \mathrm{H}), 7.79(\mathrm{~d}, \mathrm{~J}=7.9 \mathrm{~Hz}, 1 \mathrm{H}), 7.58(\mathrm{t}, \mathrm{J}=7.9 \mathrm{~Hz}, 1 \mathrm{H}), 7.51(\mathrm{~d}, \mathrm{~J}=3.5 \mathrm{~Hz}, 1 \mathrm{H})$, $7.16(\mathrm{t}, \mathrm{J}=7.6 \mathrm{~Hz}, 1 \mathrm{H}), 6.56(\mathrm{~d}, \mathrm{~J}=3.5 \mathrm{~Hz}, 1 \mathrm{H}), 5.51(\mathrm{~s}, 2 \mathrm{H}), 3.52(\mathrm{t}, \mathrm{J}=8.0 \mathrm{~Hz}, 2 \mathrm{H}), 2.82(\mathrm{~d}, \mathrm{~J}$ $=4.4 \mathrm{~Hz}, 3 \mathrm{H}), 0.84(\mathrm{t}, \mathrm{J}=8.1 \mathrm{~Hz}, 2 \mathrm{H}),-0.08(\mathrm{~s}, 9 \mathrm{H}) .{ }^{13} \mathrm{CNMR}(126 \mathrm{MHz}, \mathrm{dmso}) \delta$ 169.60, 153.90, $152.61,151.34,140.04,132.42,128.62,127.74,122.56,121.28,121.13,103.84,98.70,72.98$, $66.03,40.50,40.34,40.17,40.00,39.83,39.67,39.50,26.82,17.53,-0.96$.

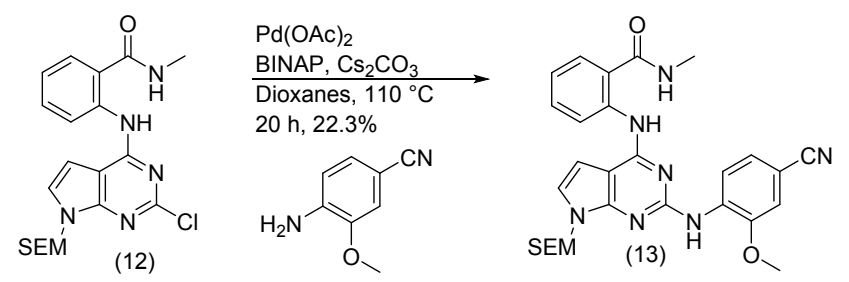

2-((2-((4-Cyano-2-methoxyphenyl)amino)-7-((2-(trimethylsilyl)ethoxy)methyl)-7H-pyrrolo[2,3d]pyrimidin-4-yl)amino)-N-methylbenzamide (13)

Compound 13 was prepared using protocols described in the literature. ${ }^{2} \mathrm{~A}$ flame dried three neck flask was charged with $201.1 \mathrm{mg}$ of 12 (0.463 mmol, 1 equiv), $795.6 \mathrm{mg}$ of $\mathrm{Cs}_{2} \mathrm{CO}_{3}$ (2.32 $\mathrm{mmol}, 5$ equiv.), $60.3 \mathrm{mg}$ of BINAP, racemic ( $0.00927 \mathrm{mmol}, 0.2$ equiv.), $\mathrm{Pd}(\mathrm{OAc})_{2}(0.1$ equiv., $5 \mathrm{~mol} \%)$, and $84.1 \mathrm{mg}$ of 4-amino-3-methoxybenzonitrile $(0.555 \mathrm{mmol} 1.2$ equiv.). The mixture was degassed with three cycles of evacuation and back filled with nitrogen and $4 \mathrm{~mL}$ of dioxanes added. The solution was further degassed with an additional 4 cycles of evacuation and back filled with nitrogen, then heated to $110{ }^{\circ} \mathrm{C}$ for $20 \mathrm{~h}$. The reaction mixture was passed through a pad of celite, washing with EtOAc and purified by column chromatography eluting with $50 \%$ EtOAc/Hexanes to afford a dark red solid $56.2 \mathrm{mg}, 22.3 \%$ HPLC: $8.912 \mathrm{~min}$, Molecular Formula: $\mathrm{C}_{28} \mathrm{H}_{33} \mathrm{~N}_{7} \mathrm{O}_{3} \mathrm{Si}$, Mass Calc: 543.24 ESI-MS-Found: 544.17 [M+1], purity: $90 \%{ }^{1} \mathrm{H}$ NMR (500 MHz, Chloroform-d) $\delta 11.19$ (s, 1H), 8.86 (dd, J = 8.5, 5.7 Hz, 2H), $7.78(\mathrm{~s}, 1 \mathrm{H}), 7.56-7.49(\mathrm{~m}, 2 \mathrm{H})$, $7.10-7.05(\mathrm{~m}, 2 \mathrm{H}), 7.01(\mathrm{~d}, \mathrm{~J}=3.6 \mathrm{~Hz}, 1 \mathrm{H}), 6.64(\mathrm{~d}, \mathrm{~J}=3.7 \mathrm{~Hz}, 1 \mathrm{H}), 5.56(\mathrm{~s}, 2 \mathrm{H}), 3.62-3.57$ $(\mathrm{m}, 2 \mathrm{H}), 3.05(\mathrm{~d}, \mathrm{~J}=4.8 \mathrm{~Hz}, 3 \mathrm{H}), 0.98-0.92(\mathrm{~m}, 2 \mathrm{H}),-0.07(\mathrm{~d}, \mathrm{~J}=1.0 \mathrm{~Hz}, 9 \mathrm{H}) .{ }^{13} \mathrm{CNMR}(126$ $\mathrm{MHz}$, dmso) $\delta 169.62,163.07,158.90,153.91,152.63,151.36,140.05,132.42,128.63,127.73$, 123.88, 122.57, 118.65, 117.79, 103.85, 98.72, 72.99, 66.05, 26.83, 17.53, -0.96. 


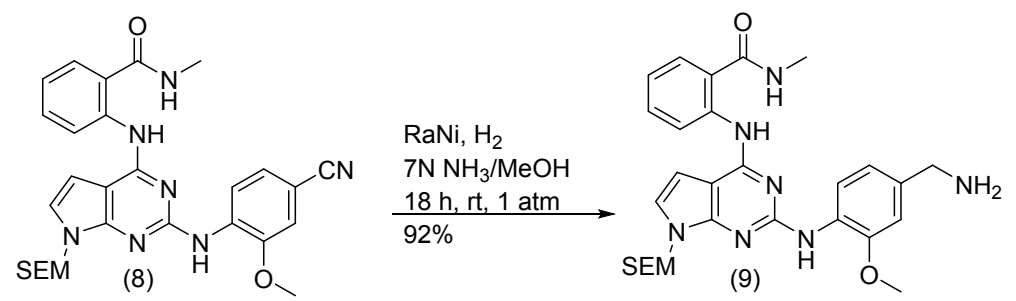

2-((2-((4-(Aminomethyl)-2-methoxyphenyl)amino)-7-((2-(trimethylsilyl)ethoxy)methyl)-7Hpyrrolo[2, 3-d]pyrimidin-4-yl)amino)-N-methylbenzamide (14)

To a dried flask were added $270.2 \mathrm{mg}$ of 13 and10 mL (13 mmol) of $7 \mathrm{~N}$ methanolic ammonia. ${ }^{3}$ The solution was degassed with three rounds of evacuation and back filled with nitrogen. RaNi (slurry in water) was added and the mixture was further degassed with three rounds of evacuation and back filled with nitrogen. The atmosphere was then replaced with hydrogen and allowed to stir under $\mathrm{H}_{2}$ for $6 \mathrm{~h}$. Once complete, $\mathrm{H}_{2}$ atmosphere was removed and the solution was passed through a pad of celite, washing with methanolic ammonia. The solvent was removed under pressure to give a light green solid, $250 \mathrm{mg}, 92 \%$. HPLC: $6.331 \mathrm{~min}$, Molecular Formula: $\mathrm{C}_{28} \mathrm{H}_{37} \mathrm{~N}_{7} \mathrm{O}_{3} \mathrm{Si}$, Mass Calc: $547.27 \mathrm{ESI}-\mathrm{MS}-$ Found: 548.2719 [M+1], purity: $97 \%$. ${ }^{1} \mathrm{HNMR}$ (500 MHz, DMSO-d6) $\delta 11.76$ (s, 1H), 8.82 (dq, J = 30.6, 7.9 Hz, 2H), 8.41 (dd, J = 32.4, $24.4 \mathrm{~Hz}, 1 \mathrm{H}$ ), $7.81(\mathrm{q}, \mathrm{J}=15.7,10.9 \mathrm{~Hz}, 1 \mathrm{H}), 7.70-7.59(\mathrm{~m}, 1 \mathrm{H}), 7.54(\mathrm{dt}, \mathrm{J}=25.5,12.4 \mathrm{~Hz}, 1 \mathrm{H}), 7.21(\mathrm{~s}, 1 \mathrm{H})$, $7.15-7.05(\mathrm{~m}, 2 \mathrm{H}), 6.93(\mathrm{dt}, \mathrm{J}=22.3,10.2 \mathrm{~Hz}, 1 \mathrm{H}), 6.46(\mathrm{~s}, 1 \mathrm{H}), 5.49(\mathrm{~d}, \mathrm{~J}=18.2 \mathrm{~Hz}, 2 \mathrm{H}), 4.08$ $-4.04(\mathrm{~m}, 2 \mathrm{H}), 3.90(\mathrm{~d}, \mathrm{~J}=25.2 \mathrm{~Hz}, 3 \mathrm{H}), 3.62-3.54(\mathrm{~m}, 3 \mathrm{H}), 2.86(\mathrm{~s}, 3 \mathrm{H}), 0.93-0.87(\mathrm{~m}, 2 \mathrm{H})$, $-0.08(\mathrm{~d}, \mathrm{~J}=10.4 \mathrm{~Hz}, 9 \mathrm{H}){ }^{13} \mathrm{CNMR}(126 \mathrm{MHz}, \mathrm{dmso}) \delta 170.66,169.78,155.97,153.45,152.36$, $148.46,141.03,134.79,132.16,128.36,126.19,124.07,121.24,121.13,119.91,119.23,117.65$, $113.43,108.23,99.45,98.55,72.40,65.67,60.11,56.03,26.68,17.46,-1.09$.

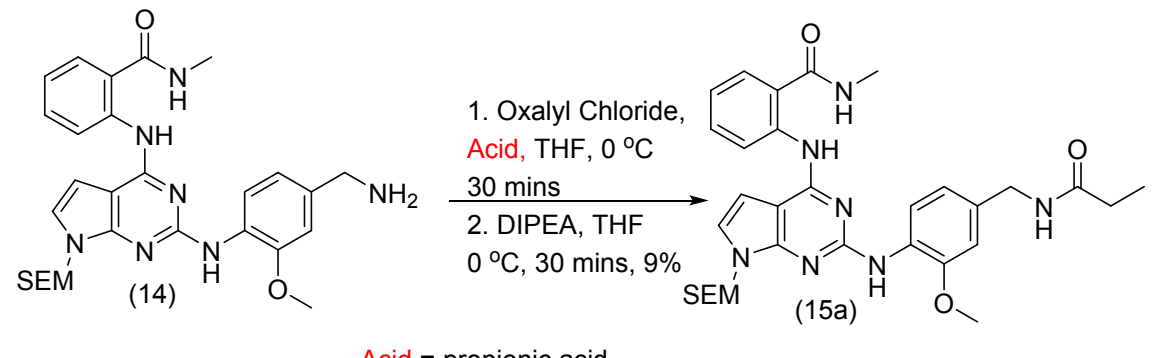

Acid $=$ propionic acid

2-((2-((2-methoxy-4-(propionamidomethyl)phenyl)amino)-7-((2-(trimethylsilyl)ethoxy)methyl)-7Hpyrrolo[2,3-d]pyrimidin-4-yl)amino)-N-methylbenzamide (15a)

A dried flask was charged with $0.02 \mathrm{~mL}$ of propionic acid ( $0.0913 \mathrm{mmol}, 1$ equiv), 2 drops of DMF, and $2 \mathrm{~mL}$ of DCM $(40 \mathrm{mmol})$. The mixture was cooled to $0{ }^{\circ} \mathrm{C}$ and $0.04 \mathrm{~mL}$ of oxalyl chloride $(5$ equiv., $0.5 \mathrm{mmol}$ ) were added. The mixture was allowed to warm to $\mathrm{rt}$ and stir for $1 \mathrm{~h}$. Once complete, the solvent was removed under pressure and the light green residue was rinsed with DCM $(3 \times 10 \mathrm{~mL})$. The green residue was then taken up in DCM $(2 \mathrm{~mL}, 40 \mathrm{mmol})$, and the mixture was cooled back to $0{ }^{\circ} \mathrm{C}$. At $0{ }^{\circ} \mathrm{C}$ were added $0.1 \mathrm{~mL}$ of DIPEA $(0.0913 \mathrm{mmol}, 1.0$ equiv.), and $50.4 \mathrm{mg}$ of 14 ( 1 equiv, $0.09 \mathrm{mmol}$ ). The solution was warmed to rt for $3 \mathrm{~h}$. Once complete the solvent was removed. The dark yellow residue was purified by preparatory TLC plate (EtOAc/1\% $\mathrm{MeOH})$. The band containing the desired material was collected, and the material was eluted off silica gel with acetone. The solvent was removed to give a light yellow solid, $5 \mathrm{mg}, 9 \%$. HPLC: 7.04 min, Molecular Formula: $\mathrm{C}_{31} \mathrm{H}_{41} \mathrm{~N}_{7} \mathrm{O}_{4} \mathrm{Si}$, Mass Calc: 603.30 ESI-MS-Found: 604 [M+1], purity: $90 \%$. ${ }^{1} \mathrm{HNMR}(700 \mathrm{MHz}$, DMSO-d6) $\delta 11.69(\mathrm{~s}, 1 \mathrm{H}), 8.82-8.78(\mathrm{~m}, 1 \mathrm{H}), 8.75(\mathrm{~d}, \mathrm{~J}=4.8 \mathrm{~Hz}, 1 \mathrm{H})$, $8.33(\mathrm{~d}, \mathrm{~J}=8.1 \mathrm{~Hz}, 1 \mathrm{H}), 8.22(\mathrm{t}, \mathrm{J}=5.8 \mathrm{~Hz}, 1 \mathrm{H}), 7.95(\mathrm{~s}, 1 \mathrm{H}), 7.75(\mathrm{dd}, \mathrm{J}=7.9,1.6 \mathrm{~Hz}, 1 \mathrm{H}), 7.63$ 
(s, 1H), $7.52-7.46(\mathrm{~m}, 1 \mathrm{H}), 7.18(\mathrm{~d}, \mathrm{~J}=3.6 \mathrm{~Hz}, 1 \mathrm{H}), 7.07(\mathrm{td}, \mathrm{J}=7.7,1.2 \mathrm{~Hz}, 1 \mathrm{H}), 6.94(\mathrm{~d}, \mathrm{~J}=$ $1.8 \mathrm{~Hz}, 1 \mathrm{H}), 6.83(\mathrm{dd}, \mathrm{J}=8.2,1.8 \mathrm{~Hz}, 1 \mathrm{H}), 6.41(\mathrm{~d}, \mathrm{~J}=3.6 \mathrm{~Hz}, 1 \mathrm{H}), 5.47(\mathrm{~s}, 2 \mathrm{H}), 4.24(\mathrm{~d}, \mathrm{~J}=5.9$ $\mathrm{Hz}, 2 \mathrm{H}), 3.87(\mathrm{~s}, 3 \mathrm{H}), 3.57-3.51(\mathrm{~m}, 2 \mathrm{H}), 2.82(\mathrm{~d}, \mathrm{~J}=4.5 \mathrm{~Hz}, 3 \mathrm{H}), 2.15(\mathrm{q}, \mathrm{J}=7.6 \mathrm{~Hz}, 2 \mathrm{H}), 1.04$ $(\mathrm{t}, \mathrm{J}=7.6 \mathrm{~Hz}, 3 \mathrm{H}), 0.89-0.84(\mathrm{~m}, 2 \mathrm{H}),-0.10(\mathrm{~s}, 9 \mathrm{H}) .{ }^{13} \mathrm{CNMR}(176 \mathrm{MHz}, \mathrm{dmso}) \delta 173.25,169.89$, $162.79,156.06,153.56,152.46,148.64,141.08,133.36,132.27,128.68,124.24,121.39,120.11$, $119.49,118.29,110.20,99.53,98.65,72.54,65.79,56.15,42.47,29.04,26.81,17.58,10.55$, 0.95 .

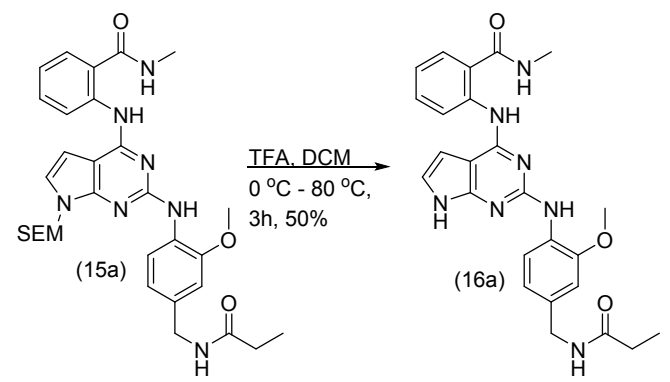

2-((2-((2-methoxy-4-(propionamidomethyl)phenyl)amino)-7H-pyrrolo[2,3-d]pyrimidin-4-yl)amino)$\mathrm{N}$-methylbenzamide (16a, CCG-264561)

A dried flask was charged with $5 \mathrm{mg}$ of $15 \mathrm{a}$ ( $8 \mu \mathrm{mol}, 1.0$ equiv), and $2 \mathrm{~mL}$ of DCM. The solution was cooled to $0{ }^{\circ} \mathrm{C}$, and $0.08 \mathrm{~mL}$ of TFA (25 equiv., $0.2 \mathrm{mmol}$ ) were added in one portion. The solution was warmed to $80{ }^{\circ} \mathrm{C}$ and stirred until complete. Once complete, the solvent was removed, and the residue was rinsed with $\mathrm{DCM}(3 \times 5 \mathrm{~mL})$. The yellow residue was then purified by preparatory TLC plate ( $1 \% \mathrm{MeOH} / \mathrm{EtOAC})$. The band containing the desired material was collected, and the material was washed off silica gel with $\mathrm{MeOH}$. The solvent was removed to give a light yellow oil, $2.0 \mathrm{mg}, 50 \%$. HPLC: $4.99 \mathrm{~min}$, Molecular Formula: $\mathrm{C}_{25} \mathrm{H}_{27} \mathrm{~N}_{7} \mathrm{O}_{3}$, Mass Calc: 473.22 ESI-MS-Found: 474 [M+1], purity: 92\% ${ }^{1} \mathrm{HNMR}(700 \mathrm{MHz}$, DMSO-d6) $\delta 11.68(\mathrm{~s}, 1 \mathrm{H})$, $8.80(\mathrm{~d}, \mathrm{~J}=8.3 \mathrm{~Hz}, 1 \mathrm{H}), 8.75(\mathrm{~d}, \mathrm{~J}=5.1 \mathrm{~Hz}, 1 \mathrm{H}), 8.28(\mathrm{~d}, \mathrm{~J}=7.9 \mathrm{~Hz}, 1 \mathrm{H}), 8.23(\mathrm{~s}, 1 \mathrm{H}), 7.75(\mathrm{~d}, \mathrm{~J}$ $=7.7 \mathrm{~Hz}, 1 \mathrm{H}), 7.60(\mathrm{~s}, 1 \mathrm{H}), 7.47(\mathrm{t}, \mathrm{J}=7.9 \mathrm{~Hz}, 1 \mathrm{H}), 7.13(\mathrm{~d}, \mathrm{~J}=3.6 \mathrm{~Hz}, 1 \mathrm{H}), 7.06(\mathrm{t}, \mathrm{J}=7.5 \mathrm{~Hz}$, $1 \mathrm{H}), 6.93(\mathrm{~s}, 1 \mathrm{H}), 6.84(\mathrm{~d}, \mathrm{~J}=8.1 \mathrm{~Hz}, 1 \mathrm{H}), 6.46(\mathrm{t}, \mathrm{J}=7.3 \mathrm{~Hz}, 1 \mathrm{H}), 6.38(\mathrm{~d}, \mathrm{~J}=3.6 \mathrm{~Hz}, 1 \mathrm{H}), 4.24$ $(\mathrm{d}, \mathrm{J}=5.9 \mathrm{~Hz}, 2 \mathrm{H}), 3.86(\mathrm{~d}, \mathrm{~J}=4.3 \mathrm{~Hz}, 3 \mathrm{H}), 2.82(\mathrm{~d}, \mathrm{~J}=4.5 \mathrm{~Hz}, 3 \mathrm{H}), 2.16$ (dd, J = 10.7, $4.7 \mathrm{~Hz}$, 2H), 1.05 (t, J = 7.6 Hz, 3H). ${ }^{13} \mathrm{CNMR}(176 \mathrm{MHz}$, dmso) $\delta 173.25,169.89,162.79,156.06,153.56$, 152.46, 148.64, 141.08, 133.36, 132.27, 128.68, 124.24, 121.39, 120.11, 119.49, 118.29, 110.20, 99.53, 92.08, 56.15, 42.47, 29.04, 26.81,10.55.

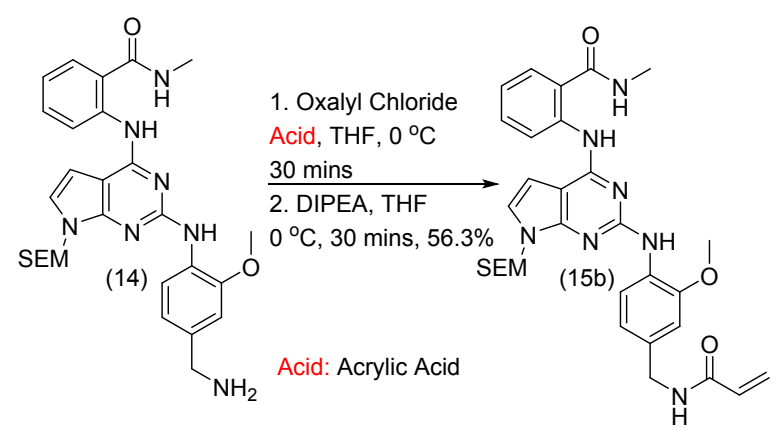

2-((2-((4-(acrylamidomethyl)-2-methoxyphenyl)amino)-7-((2-(trimethylsilyl)ethoxy)methyl)-7Hpyrrolo[2,3-d]pyrimidin-4-yl)amino)- $N$-methylbenzamide (15b)

A dried flask was charged with $0.05 \mathrm{~mL}$ of acrylic acid $(0.219 \mathrm{mmol}, 1$ equiv), 2 drops of DMF and $2 \mathrm{~mL}$ of THF ( 0.1 molar). The mixture was cooled to $0{ }^{\circ} \mathrm{C}$ and $0.1 \mathrm{~mL}$ of oxalyl chloride $(1.14 \mathrm{mmol}$, 5.1 equiv) were added. The solution was allowed to warm to $\mathrm{rt}$ for $1 \mathrm{~h}$. Once complete, the solvent 
was removed under pressure and the light green residue was rinsed with $\mathrm{DCM}(3 \times 10 \mathrm{~mL})$. The light green residue was then taken up in DCM ( $5 \mathrm{~mL}, 40 \mathrm{mmol})$ and cooled to $0{ }^{\circ} \mathrm{C}$. At $0{ }^{\circ} \mathrm{C}, 120$ $\mathrm{mg}$ of 14 ( $0.219 \mathrm{mmol}, 1$ equiv) and $0.1 \mathrm{~mL}$ of DIPEA $(0.57 \mathrm{mmol}, 2.6$ equiv) were added. The solution warmed to rt and stirred until reaction was complete. Once complete, the solvent was removed, evaporating product onto silica gel. The material was purified by column chromatography (EtOAc/Hex). The major product was eluted in $\mathrm{MeOH}$ and collected to give a light yellow solid, $70.6 \mathrm{mg}, 53.6 \%$. HPLC: $7.24 \mathrm{~min}$, Molecular Formula: $\mathrm{C}_{31} \mathrm{H}_{39} \mathrm{~N}_{7} \mathrm{O}_{4} \mathrm{Si}$, Mass Calc: 601.28 ESI-MS-Found: 674 [M+Acrylic Acid], purity: 90\%. ${ }^{1} \mathrm{HNMR}$ (700 MHz, DMSO-d6) $\delta 11.71$ $(\mathrm{d}, \mathrm{J}=4.9 \mathrm{~Hz}, 1 \mathrm{H}), 8.80$ (dt, J = 8.5, 3.0 Hz, 1H), 8.75 (q, J = 4.4 Hz, 1H), $8.55(\mathrm{t}, \mathrm{J}=5.9 \mathrm{~Hz}, 1 \mathrm{H})$, $8.35(\mathrm{~d}, \mathrm{~J}=8.0 \mathrm{~Hz}, 1 \mathrm{H}), 7.95(\mathrm{~s}, 1 \mathrm{H}), 7.76(\mathrm{dt}, \mathrm{J}=8.0,2.0 \mathrm{~Hz}, 1 \mathrm{H}), 7.64(\mathrm{~s}, 1 \mathrm{H}), 7.49$ (ddd, J = 8.5, 7.1, 1.5 Hz, 1H), 7.20 - $7.17(\mathrm{~m}, 1 \mathrm{H}), 7.10-7.04(\mathrm{~m}, 1 \mathrm{H}), 6.97(\mathrm{~d}, \mathrm{~J}=1.8 \mathrm{~Hz}, 1 \mathrm{H}), 6.86(\mathrm{dd}$, $\mathrm{J}=8.2,1.8 \mathrm{~Hz}, 1 \mathrm{H}), 6.42(\mathrm{dd}, \mathrm{J}=3.6,1.6 \mathrm{~Hz}, 1 \mathrm{H}), 6.33-6.27(\mathrm{~m}, 1 \mathrm{H}), 6.17-6.12(\mathrm{~m}, 1 \mathrm{H}), 5.47$ $(\mathrm{s}, 2 \mathrm{H}), 4.34(\mathrm{t}, \mathrm{J}=6.0 \mathrm{~Hz}, 2 \mathrm{H}), 3.87(\mathrm{~d}, \mathrm{~J}=4.5 \mathrm{~Hz}, 3 \mathrm{H}), 3.58-3.51(\mathrm{~m}, 2 \mathrm{H}), 2.82(\mathrm{~d}, \mathrm{~J}=4.4 \mathrm{~Hz}$, $3 \mathrm{H}), 0.88-0.84(\mathrm{~m}, 2 \mathrm{H}),-0.10(\mathrm{~s}, 9 \mathrm{H}) .{ }^{13} \mathrm{CNMR}(176 \mathrm{MHz}, \mathrm{dmso}) \delta 169.38,164.43,162.26$, 155.53, 153.05, 151.94, 148.15, 140.58, 132.31, 131.76, 128.36, 127.95, 125.19, 123.73, 120.87, $120.76,119.57,119.28,119.10,109.93,99.06,98.14,72.04,65.29,55.67,42.21,26.29,17.08$, -1.46 .

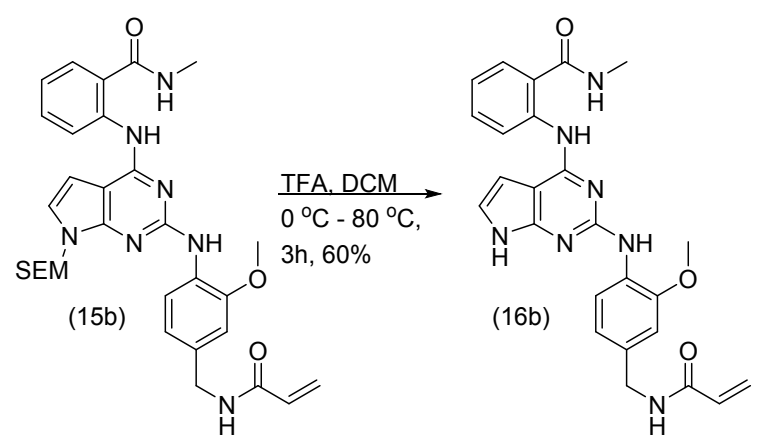

2-((2-((4-(acrylamidomethyl)-2-methoxyphenyl)amino)-7H-pyrrolo[2, 3-d]pyrimidin-4-yl)amino)$\mathrm{N}$-methylbenzamide (16b, CCG-264099)

A dried flask was charged with $10 \mathrm{mg}$ of $15 \mathrm{~b}$ (0.008 mmol, 1.0 equiv), and $2 \mathrm{~mL}$ of DCM (4 mmol). The solution was cooled to $0{ }^{\circ} \mathrm{C}$, and $0.20 \mathrm{~mL}$ of TFA (150 equiv.) were added in one portion. The dark red solution warmed to $80{ }^{\circ} \mathrm{C}$ for $3 \mathrm{~h}$. Once complete, the mixture was cooled to rt and quenched with saturated $\mathrm{K}_{2} \mathrm{CO}_{3}$ in $\mathrm{MeOH}$. The mixture was then extracted with $\mathrm{DCM}(3 \times 30 \mathrm{~mL})$ and the combined organic layers were washed with brine $(1 \times 30 \mathrm{~mL})$. The organic layer was dried over $\mathrm{MgSO}_{4}$ and then purified by preparatory TLC plate $(50 \% \mathrm{EtOAc} / \mathrm{Hex}$ with $5 \% \mathrm{MeOH})$ to yield a white solid, $4.7 \mathrm{mg}, 60 \%$. HPLC: $5.750 \mathrm{~min}$, Molecular Formula: $\mathrm{C}_{25} \mathrm{H}_{25} \mathrm{~N}_{7} \mathrm{O}_{3}$, Mass Calc: 471.20 ESI-MS-Found: 472 [M+1], purity: 96\%. ${ }^{1} \mathrm{HNMR}(700 \mathrm{MHz}, \mathrm{DMSO}-\mathrm{d} 6) \delta 11.43(\mathrm{~s}, 1 \mathrm{H}), 10.72$ (s, $1 \mathrm{H}), 8.78(\mathrm{~d}, \mathrm{~J}=8.8 \mathrm{~Hz}, 1 \mathrm{H}), 8.55(\mathrm{t}, \mathrm{J}=5.8 \mathrm{~Hz}, 1 \mathrm{H}), 8.22(\mathrm{~d}, \mathrm{~J}=8.1 \mathrm{~Hz}, 1 \mathrm{H}), 7.97(\mathrm{dd}, \mathrm{J}=8.0$, $1.6 \mathrm{~Hz}, 1 \mathrm{H}), 7.61-7.56(\mathrm{~m}, 2 \mathrm{H}), 7.10(\mathrm{t}, \mathrm{J}=7.9 \mathrm{~Hz}, 1 \mathrm{H}), 7.03(\mathrm{dd}, \mathrm{J}=3.5,2.2 \mathrm{~Hz}, 1 \mathrm{H}), 6.96(\mathrm{~d}$, $\mathrm{J}=1.8 \mathrm{~Hz}, 1 \mathrm{H}), 6.85(\mathrm{dd}, \mathrm{J}=8.2,1.8 \mathrm{~Hz}, 1 \mathrm{H}), 6.40(\mathrm{dd}, \mathrm{J}=3.5,1.9 \mathrm{~Hz}, 1 \mathrm{H}), 6.33-6.24(\mathrm{~m}, 1 \mathrm{H})$, 6.14 (dd, J = 17.1, 2.3 Hz, 1H), 5.62 (dd, J = 10.2, 2.2 Hz, 1H), 4.33 (d, J = 5.9 Hz, 2H), 3.86 (d, $\mathrm{J}=8.8 \mathrm{~Hz}, 6 \mathrm{H}) . .{ }^{13} \mathrm{CNMR}(176 \mathrm{MHz}$, dmso) $\delta$ 168.98, 164.94, 155.90, 153.28, 152.97, 149.14, 142.41, 134.50, 133.02, 132.25, 131.05, 128.99, 125.74, 121.55, 121.40, 121.11, 119.83, 116.30, 110.55, 99.56, 97.82, 56.17, 42.78, 26.29, 17.08 . 


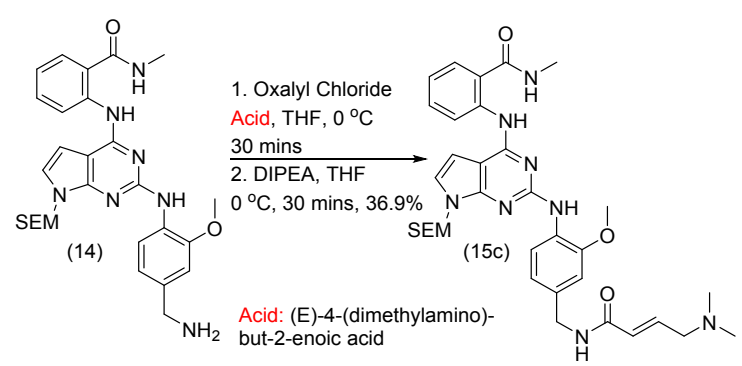

(E)-2-((2-((4-((4-(dimethylamino)but-2-enamido)methyl)-2-methoxyphenyl)amino)-7-((2(trimethylsilyl)ethoxy)methyl)-7H-pyrrolo[2,3-d]pyrimidin-4-yl)amino)-N-methylbenzamide (15c)

A dried flask was charged with $29.7 \mathrm{mg}$ of (E)-4-(dimethylamino)but-2-enoic acid (1.0 equiv., $0.219 \mathrm{mmol}), 3$ drops of DMF, and $2 \mathrm{~mL}$ of THF $(0.1$ molar $)$. . The mixture was cooled to $0{ }^{\circ} \mathrm{C}$ and $0.02 \mathrm{~mL}$ of oxalyl chloride (1.1 equiv., $0.241 \mathrm{mmol}$ ) were added. The solution was warmed to rt and allowed for $1 \mathrm{~h}$. Once complete, the solvent was removed under pressure and the light green residue was rinsed with DCM $(3 \times 10 \mathrm{~mL})$. The light green residue was then taken up in THF ( $5 \mathrm{~mL}, 40 \mathrm{mmol}$ ) and cooled to $0{ }^{\circ} \mathrm{C}$. At $0{ }^{\circ} \mathrm{C}$ were added $120.0 \mathrm{mg}$ of $14(0.219 \mathrm{mmol}, 1.0$ equiv) and $0.1 \mathrm{~mL}$ of DIPEA (2.6 equiv., $0.57 \mathrm{mmol}$ ). The mixture was warmed to $\mathrm{rt}$ and stirred until reaction was complete. Once complete, the solvent was removed, evaporating product onto silica gel. The material was purified by column chromatography $(30-50 \%$ EtOAc/Hex). The major product was collected, and the solvent was removed under pressure to give a light yellow solid, 53.2 mg, 36.9\% HPLC: 7.288 min, Molecular Formula: $\mathrm{C}_{34} \mathrm{H}_{46} \mathrm{~N}_{8} \mathrm{O}_{4} \mathrm{Si}$, Mass Calc: $658.34 \mathrm{ESI}-\mathrm{MS}-$ Found: $659.3460[\mathrm{M}+\mathrm{H}]$, purity: $80 \%$. ${ }^{1} \mathrm{HNMR}(700 \mathrm{MHz}$, Chloroform-d) $\delta 8.91$ (dd, J = 11.7, 8.4 $\mathrm{Hz}, 2 \mathrm{H}), 8.64-8.60(\mathrm{~m}, 2 \mathrm{H}), 8.10(\mathrm{dd}, \mathrm{J}=20.4,7.9 \mathrm{~Hz}, 1 \mathrm{H}), 7.66(\mathrm{~s}, 1 \mathrm{H}), 7.64(\mathrm{~d}, \mathrm{~J}=8.1 \mathrm{~Hz}$, $2 \mathrm{H}), 7.28(\mathrm{~d}, \mathrm{~J}=1.9 \mathrm{~Hz}, 1 \mathrm{H}), 7.20(\mathrm{t}, \mathrm{J}=7.3 \mathrm{~Hz}, 2 \mathrm{H}), 7.00(\mathrm{~s}, 1 \mathrm{H}), 6.99(\mathrm{~d}, \mathrm{~J}=2.0 \mathrm{~Hz}, 1 \mathrm{H}), 6.98$ $(\mathrm{s}, 1 \mathrm{H}), 6.83(\mathrm{~d}, \mathrm{~J}=1.7 \mathrm{~Hz}, 1 \mathrm{H}), 6.32(\mathrm{~d}, \mathrm{~J}=7.7 \mathrm{~Hz}, 1 \mathrm{H}), 5.97(\mathrm{~d}, \mathrm{~J}=15.3 \mathrm{~Hz}, 1 \mathrm{H}), 5.53(\mathrm{~s}, 2 \mathrm{H})$, $4.47(\mathrm{~d}, \mathrm{~J}=5.6 \mathrm{~Hz}, 2 \mathrm{H}), 3.91(\mathrm{~s}, 3 \mathrm{H}), 3.55(\mathrm{dt}, \mathrm{J}=8.3,2.2 \mathrm{~Hz}, 3 \mathrm{H}), 3.07(\mathrm{dd}, \mathrm{J}=6.2,1.6 \mathrm{~Hz}, 2 \mathrm{H})$, $3.02(\mathrm{~d}, \mathrm{~J}=4.7 \mathrm{~Hz}, 3 \mathrm{H}), 2.18(\mathrm{~s}, 6 \mathrm{H}), 0.88(\mathrm{t}, \mathrm{J}=6.9 \mathrm{~Hz}, 2 \mathrm{H}),-0.09(\mathrm{~s}, 9 \mathrm{H}) .{ }^{13} \mathrm{CNMR}(176 \mathrm{MHz}$, cdcl3) $\delta 168.97,167.63,166.29,155.12,151.63,147.90,143.92,143.34,132.23,130.15,128.90$, $122.70,121.88,120.48,118.89,117.88,117.18,116.44,111.80,104.18,100.23,87.02,66.28$, 63.24, 55.93, 49.42, 44.04, 26.99, 23.95, -1.29.

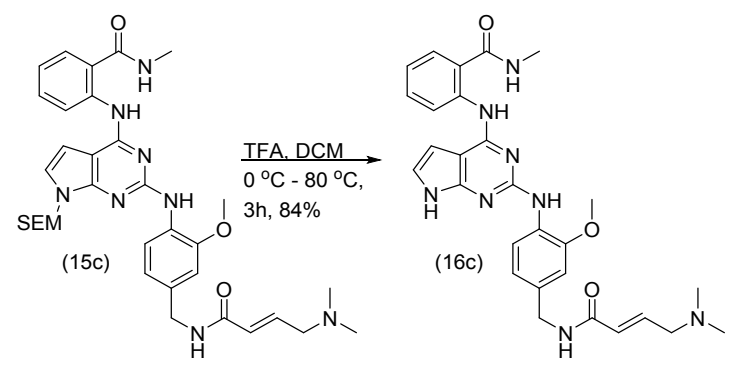

(E)-2-((2-((4-((4-(dimethylamino)but-2-enamido)methyl)-2-methoxyphenyl)amino)-7Hpyrrolo[2,3-d]pyrimidin-4-yl)amino)-N-methylbenzamide (16c):

Compound 16c was synthesized using the protocol described for $16 \mathrm{~b}$. Yields a bright yellow solid, 40.5 mg, 84\%. HPLC: 4.72 min, Molecular Formula: $\mathrm{C}_{28} \mathrm{H}_{32} \mathrm{~N}_{8} \mathrm{O}_{3}$, Mass Calc: 528.26 ESI-MSFound: 559 [M+MeOH], purity: 95\%. ${ }^{1} \mathrm{HNMR}(700 \mathrm{MHz}, \mathrm{DMSO}-\mathrm{d6}) \delta 11.69(\mathrm{~s}, 2 \mathrm{H}), 8.81(\mathrm{~d}, \mathrm{~J}=$ $8.4 \mathrm{~Hz}, 1 \mathrm{H}), 8.75(\mathrm{~s}, 1 \mathrm{H}), 8.32-8.28(\mathrm{~m}, 2 \mathrm{H}), 7.76(\mathrm{~d}, \mathrm{~J}=8.0 \mathrm{~Hz}, 1 \mathrm{H}), 7.60(\mathrm{~s}, 1 \mathrm{H}), 7.48(\mathrm{t}, \mathrm{J}=$ $7.7 \mathrm{~Hz}, 1 \mathrm{H}), 7.14(\mathrm{~d}, \mathrm{~J}=3.3 \mathrm{~Hz}, 1 \mathrm{H}), 7.07(\mathrm{t}, \mathrm{J}=7.3 \mathrm{~Hz}, 1 \mathrm{H}), 6.94(\mathrm{~s}, 1 \mathrm{H}), 6.85(\mathrm{~d}, \mathrm{~J}=8.1 \mathrm{~Hz}$, $1 \mathrm{H}), 6.46(\mathrm{~s}, 1 \mathrm{H}), 6.39(\mathrm{~d}, \mathrm{~J}=3.4 \mathrm{~Hz}, 1 \mathrm{H}), 4.25-4.21(\mathrm{~m}, 2 \mathrm{H}), 3.87(\mathrm{~s}, 3 \mathrm{H}), 3.06(\mathrm{~m}, 2 \mathrm{H}), 2.83$ $(\mathrm{d}, \mathrm{J}=4.4 \mathrm{~Hz}, 3 \mathrm{H}), 2.18(\mathrm{~s}, 6 \mathrm{H}) .{ }^{13} \mathrm{CNMR}(176 \mathrm{MHz}, \mathrm{dmso}) \delta 168.73,167.68,166.40,155.97$, $150.40,147.03,144.02$, 143.35, 132.93, 130.30, 128.36, 122.80, 121.68, 120.05, 118.89, 117.96, $117.13,116.36,111.84,99.30,91.72,63.80,60.57,55.97,46.71,43.98,26.73$. 


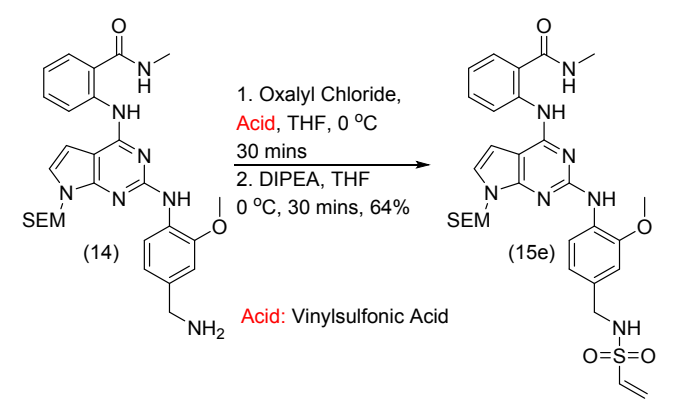

2-((2-((2-methoxy-4-(vinylsulfonamidomethyl)phenyl)amino)-7-((2-(trimethylsilyl)ethoxy)methyl)7H-pyrrolo[2,3-d]pyrimidin-4-yl)amino)-N-methylbenzamide (15e)

Compound 15e was synthesized using the protocol described for 15a. Yields a yellow solid, 15 mg, 64\%. HPLC: 7.163 min, Molecular Formula: $\mathrm{C}_{30} \mathrm{H}_{39} \mathrm{~N}_{7} \mathrm{O}_{5} \mathrm{SSi}$, Mass Calc: 637.25, ESI-MSFound: 638 [M+1], purity: 95\% ${ }^{1} \mathrm{HNMR}(700 \mathrm{MHz}$, Chloroform-d) $\delta 11.61(\mathrm{~s}, 1 \mathrm{H}), 8.93(\mathrm{~d}, \mathrm{~J}=8.5 \mathrm{~Hz}$, $1 \mathrm{H}), 8.29(\mathrm{~s}, 1 \mathrm{H}), 8.10(\mathrm{~d}, \mathrm{~J}=7.2 \mathrm{~Hz}, 1 \mathrm{H}), 8.05(\mathrm{~s}, 2 \mathrm{H}), 7.75(\mathrm{~m}, 1 \mathrm{H}), 7.54(\mathrm{~m}, 1 \mathrm{H}), 7.42(\mathrm{~m}, 1 \mathrm{H}), 7.36(\mathrm{~s}$, $1 \mathrm{H}), 7.22(\mathrm{~d}, \mathrm{~J}=8.2 \mathrm{~Hz}, 1 \mathrm{H}), 7.05(\mathrm{~d}, \mathrm{~J}=9.2 \mathrm{~Hz}, 2 \mathrm{H}), 6.97(\mathrm{~m}, 2 \mathrm{H}), 6.25(\mathrm{~m}, 2 \mathrm{H}), 6.05(\mathrm{~d}, \mathrm{~J}=9.0 \mathrm{~Hz}, 1 \mathrm{H})$, $5.80(\mathrm{~d}, \mathrm{~J}=10.0 \mathrm{~Hz}, 1 \mathrm{H}), 5.57(\mathrm{~s}, 2 \mathrm{H}), 3.87(\mathrm{~d}, \mathrm{~J}=13.2 \mathrm{~Hz}, 3 \mathrm{H}), 3.54(\mathrm{~m}, 2 \mathrm{H}), 3.36(\mathrm{~s}, 2 \mathrm{H}), 3.04(\mathrm{~d}, \mathrm{~J}=5.1$ $\mathrm{Hz}, 3 \mathrm{H}), 0.85(\mathrm{~m}, 2 \mathrm{H}),-0.08(\mathrm{~s}, 9 \mathrm{H}) .{ }^{13} \mathrm{CNMR}(176 \mathrm{MHz}, \mathrm{cdcl} 3) \delta 168.42,167.74,154.59,151.23$, $147.52,144.10,135.80,133.05,132.47,130.63,128.35,123.63,119.80,119.02,117.86,117.16$, $116.42,110.90,103.45,100.62,86.55,66.35,56.77,45.81,26.52,23.88,-1.64$.

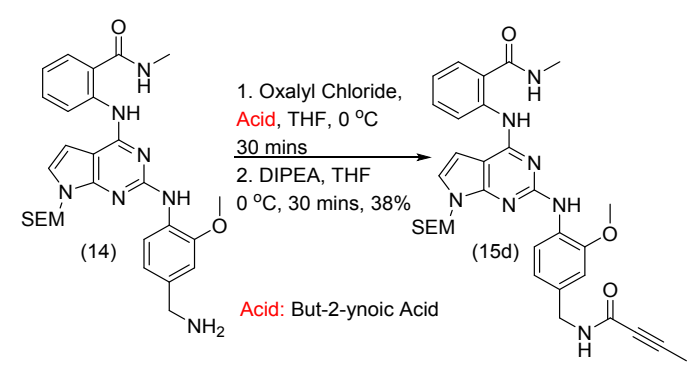

2-((2-((4-(but-2-ynamidomethyl)-2-methoxyphenyl)amino)-7-((2-(trimethylsilyl)ethoxy)methyl)7H-pyrrolo[2,3-d]pyrimidin-4-yl)amino)-N-methylbenzamide (15d)

Compound 15d was synthesized using the protocol described for 15a. Yields a light yellow solid, 15 mg, 38\%. HPLC: 7.15 min, Molecular Formula: $\mathrm{C}_{32} \mathrm{H}_{39} \mathrm{~N}_{7} \mathrm{O}_{4} \mathrm{Si}$, Mass Calc: 613.28 , ESI-MSFound: 614 [M+1], purity: 80\% ${ }^{1} \mathrm{HNMR}(700 \mathrm{MHz}$, Chloroform-d) $\delta 11.09(\mathrm{~s}, 1 \mathrm{H}), 8.91(\mathrm{~d}, \mathrm{~J}=8.4$ $\mathrm{Hz}, 1 \mathrm{H}), 8.64(\mathrm{~d}, \mathrm{~J}=8.2 \mathrm{~Hz}, 1 \mathrm{H}), 8.21(\mathrm{~s}, 1 \mathrm{H}), 7.51(\mathrm{~d}, \mathrm{~J}=7.7 \mathrm{~Hz}, 1 \mathrm{H}), 7.49(\mathrm{t}, \mathrm{J}=6.2 \mathrm{~Hz}, 1 \mathrm{H})$, $7.01(\mathrm{t}, \mathrm{J}=7.5 \mathrm{~Hz}, 1 \mathrm{H}), 6.94(\mathrm{~d}, \mathrm{~J}=3.6 \mathrm{~Hz}, 1 \mathrm{H}), 6.87(\mathrm{dd}, \mathrm{J}=8.3,1.8 \mathrm{~Hz}, 1 \mathrm{H}), 6.82(\mathrm{~d}, \mathrm{~J}=1.9$ $\mathrm{Hz}, 1 \mathrm{H}), 6.60(\mathrm{~d}, \mathrm{~J}=3.5 \mathrm{~Hz}, 1 \mathrm{H}), 6.49(\mathrm{~d}, \mathrm{~J}=5.6 \mathrm{~Hz}, 1 \mathrm{H}), 6.39(\mathrm{~d}, \mathrm{~J}=5.4 \mathrm{~Hz}, 1 \mathrm{H}), 5.53(\mathrm{~s}, 2 \mathrm{H})$, $4.42(\mathrm{~d}, \mathrm{~J}=5.7 \mathrm{~Hz}, 1 \mathrm{H}), 3.92(\mathrm{~s}, 3 \mathrm{H}), 3.51-3.43(\mathrm{~m}, 3 \mathrm{H}), 2.99(\mathrm{~s}, 3 \mathrm{H}), 1.93(\mathrm{~s}, 3 \mathrm{H}), 0.94(\mathrm{t}, \mathrm{J}=$ $8.2 \mathrm{~Hz}, 2 \mathrm{H}),-0.08$ (s, 9H). ${ }^{13} \mathrm{CNMR}(176 \mathrm{MHz}, \mathrm{cdcl} 3) \mathrm{\delta} 170.35,156.89,155.81,153.79,152.77$, $149.75,147.90,141.29,132.28,130.27,129.29,126.79,122.71,121.86,121.11,120.53,118.22$, $109.83,99.59,83.75,66.30,55.94,49.28,27.01,17.83,3.84,-1.29$. 


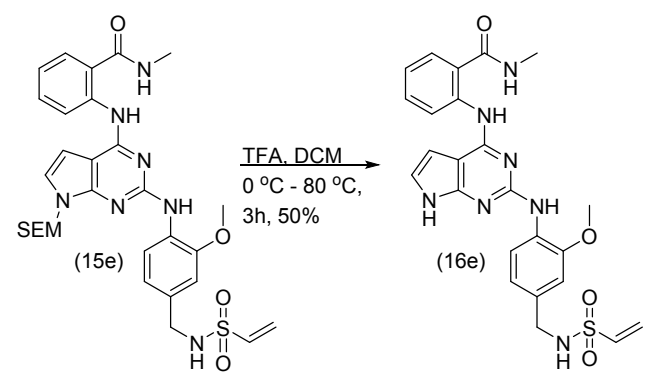

2-((2-((2-methoxy-4-(vinylsulfonamidomethyl)phenyl)amino)-7H-pyrrolo[2, 3-d]pyrimidin-4yl)amino)-N-methylbenzamide (16e)

Compound $16 \mathrm{e}$ was synthesized using the protocol described for $16 \mathrm{~b}$. Yields a yellow solid, 6 mg, 50\% HPLC: 5.7 min, Molecular Formula: $\mathrm{C}_{24} \mathrm{H}_{25} \mathrm{~N}_{7} \mathrm{O}_{4} \mathrm{~S}$, Mass Calc: 507.17 ESI-MS-Found: 508 [M+1], purity: 95\% ${ }^{1} \mathrm{H}$ NMR (700 MHz, Chloroform-d) $\delta 11.60$ (d, J = $\left.18.4 \mathrm{~Hz}, 2 \mathrm{H}\right), 9.47$ (d, J $=2.3 \mathrm{~Hz}, 1 \mathrm{H}), 9.10(\mathrm{~s}, 1 \mathrm{H}), 8.91(\mathrm{~d}, \mathrm{~J}=9.1 \mathrm{~Hz}, 1 \mathrm{H}), 8.44(\mathrm{~d}, \mathrm{~J}=7.7 \mathrm{~Hz}, 1 \mathrm{H}), 7.85(\mathrm{~s}, 1 \mathrm{H}), 7.80$ $(\mathrm{d}, \mathrm{J}=8.6 \mathrm{~Hz}, 1 \mathrm{H}), 7.56(\mathrm{~s}, 1 \mathrm{H}), 7.50-7.47(\mathrm{~m}, 1 \mathrm{H}), 7.45(\mathrm{~s}, 1 \mathrm{H}), 7.19(\mathrm{~s}, 2 \mathrm{H}), 7.14(\mathrm{~s}, 2 \mathrm{H}), 7.10$ (s, 1H), $7.06(\mathrm{~s}, 2 \mathrm{H}), 6.67(\mathrm{~d}, \mathrm{~J}=19.8 \mathrm{~Hz}, 1 \mathrm{H}), 6.28(\mathrm{~s}, 1 \mathrm{H}), 5.65(\mathrm{~s}, 1 \mathrm{H}), 3.86(\mathrm{~s}, 3 \mathrm{H}), 3.35$ (d, J $=2.7 \mathrm{~Hz}, 2 \mathrm{H}$ ), $3.04(\mathrm{~d}, \mathrm{~J}=4.4 \mathrm{~Hz}, 3 \mathrm{H}) .{ }^{13} \mathrm{CNMR}(176 \mathrm{MHz}, \mathrm{dmso}) \delta$ 168.35, 167.93, 155.05, $150.76,147.84,143.92$, 135.24, 132.83, 132.37, 130.53, 128.35, 121.68, 119.90, 118.68, 117.80, $117.14,116.46,111.78,99.28,91.81,56.08,47.41,25.80$.

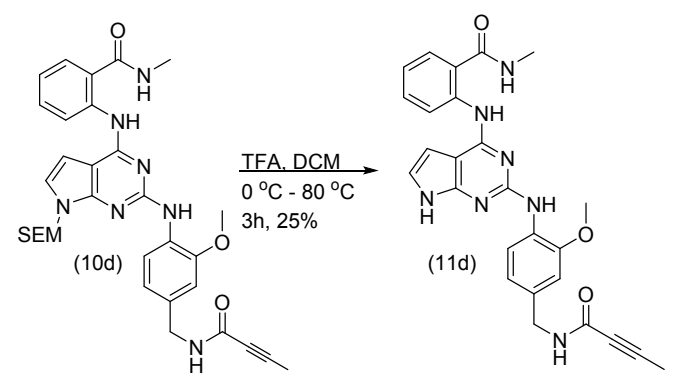

2-((2-((4-(but-2-ynamidomethyl)-2-methoxyphenyl)amino)-7H-pyrrolo[2,3-d]pyrimidin-4yl)amino)-N-methylbenzamide (16d)

Compound 16d was synthesized using the protocol described for $\mathbf{1 6 b}$. Yields a white solid, 10 mg, 25\% HPLC: 5.3 min, Molecular Formula: $\mathrm{C}_{26} \mathrm{H}_{25} \mathrm{~N}_{7} \mathrm{O}_{3}$, Mass Calc: 483.20 ESI-MS-Found: 484 [M+1], purity: 95\%. ${ }^{1} \mathrm{HNMR}(700 \mathrm{MHz}$, DMSO-d6) $\delta 11.64(\mathrm{~s}, 1 \mathrm{H}), 11.37(\mathrm{~s}, 1 \mathrm{H}), 8.95(\mathrm{t}, \mathrm{J}=$ $6.2 \mathrm{~Hz}, 1 \mathrm{H}), 8.84(\mathrm{~d}, \mathrm{~J}=8.4 \mathrm{~Hz}, 1 \mathrm{H}), 8.73(\mathrm{~d}, \mathrm{~J}=4.6 \mathrm{~Hz}, 1 \mathrm{H}), 8.23(\mathrm{~d}, \mathrm{~J}=8.1 \mathrm{~Hz}, 1 \mathrm{H}), 7.75(\mathrm{~d}$, $\mathrm{J}=7.8 \mathrm{~Hz}, 1 \mathrm{H}), 7.53(\mathrm{~s}, 1 \mathrm{H}), 7.49(\mathrm{t}, \mathrm{J}=7.9 \mathrm{~Hz}, 1 \mathrm{H}), 7.05(\mathrm{t}, \mathrm{J}=7.5 \mathrm{~Hz}, 1 \mathrm{H}), 7.01(\mathrm{~d}, \mathrm{~J}=3.3$ $\mathrm{Hz}, 1 \mathrm{H}), 6.93(\mathrm{~s}, 1 \mathrm{H}), 6.81(\mathrm{~d}, \mathrm{~J}=8.1 \mathrm{~Hz}, 1 \mathrm{H}), 6.33(\mathrm{~s}, 1 \mathrm{H}), 4.25(\mathrm{~d}, \mathrm{~J}=6.1 \mathrm{~Hz}, 2 \mathrm{H}), 3.86(\mathrm{~s}$, $3 \mathrm{H}), 2.83$ (d, J = 4.4 Hz, 3H), 1.97 (d, J = 1.1 Hz, 3H). ${ }^{13} \mathrm{CNMR}(176 \mathrm{MHz}, \mathrm{cdcl} 3) \delta 170.17$, $156.71,155.63,153.61,153.23,152.59,149.57,147.72,141.11,132.10,130.09,129.11$, 126.61, 122.53, 121.68, 120.93, 120.35, 120.02, 118.04, 109.65, 99.41, 55.76, 44.03, 26.83, 3.66 .

\section{Synthesis of 16f-j}




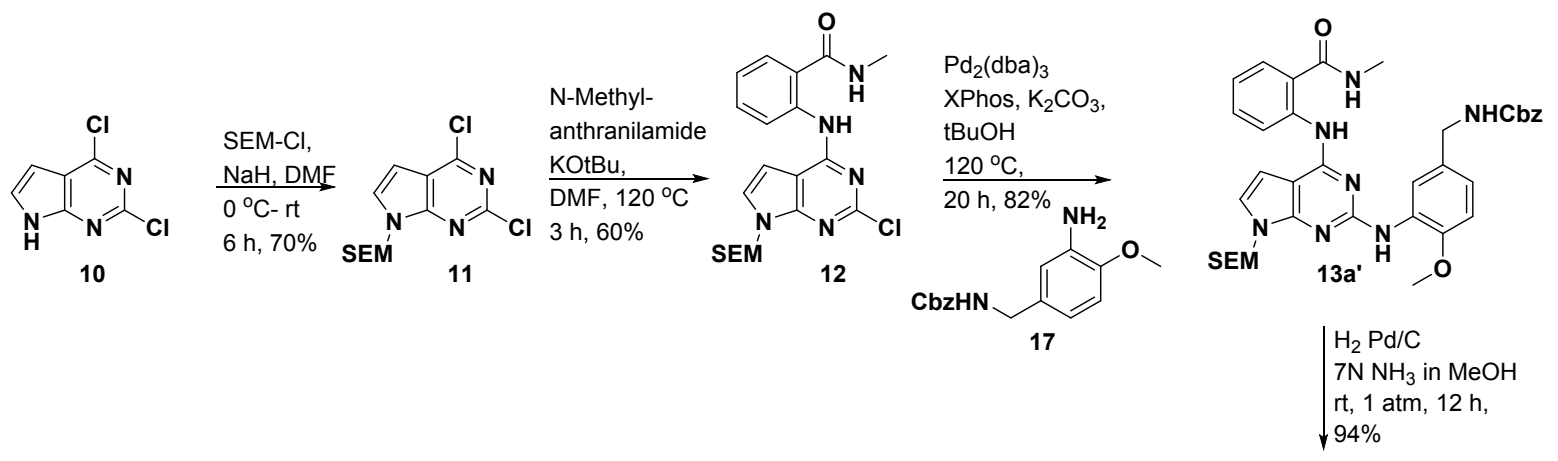

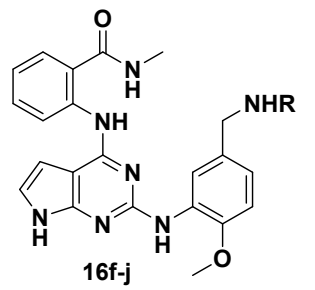

16f, $R=$ Propionic Acid $16 \mathrm{~g}, \mathrm{R}=$ Acrylic Acid 16h, R = 4-dimethylcrotonic Acid $16 i, R=2-m e t h y l b u t y n o i c ~ A c i d$ 16j, R = Vinylsulfonic Acid
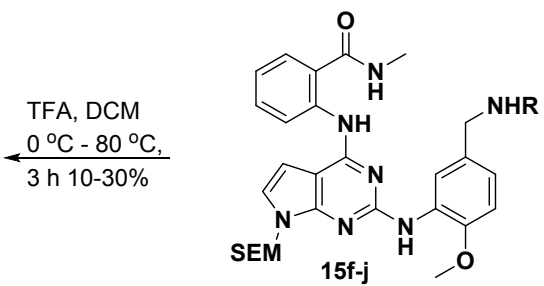

15f, $R=$ Propionic Acid $15 \mathrm{~g}, \mathrm{R}=$ Acrylic Acid 15h, R = 4-dimethylcrotonic Acid $15 i, R=2-m e t h y l b u t y n o i c$ Acid $15 \mathrm{j}, \mathrm{R}=$ Vinylsulfonic Acid

Scheme S4. Synthetic route for meta homologated compounds 16f-j.

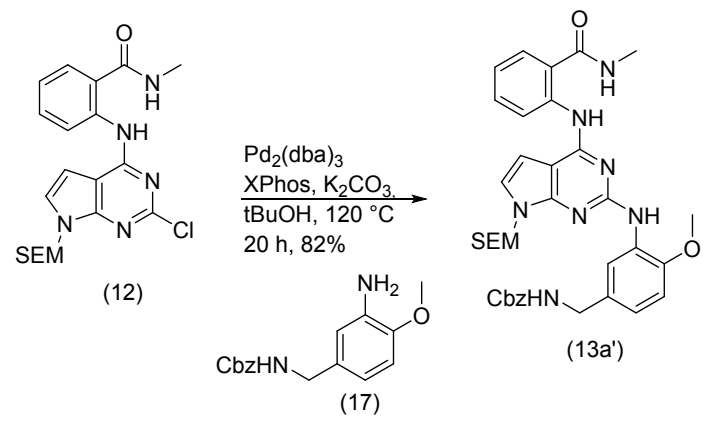

Benzyl-(4-methoxy-3-((4-((2-(methylcarbamoyl)phenyl)amino)-7-((2(trimethylsilyl)ethoxy) methyl)-7H-pyrrolo[2,3-d]pyrimidin-2-yl)amino)benzyl)carbamate (13a') A flame dried three neck flask was charged with $90.0 \mathrm{mg}$ of $12(0.21 \mathrm{mmol}, 1.0$ equiv), $68.2 \mathrm{mg}$ of $\mathrm{K}_{2} \mathrm{CO}_{3}$ (0.42 mmol, 2 equiv.), $5.5 \mathrm{mg}$ of XPhos ( $0.012 \mathrm{mmol}, 0.055$ equiv), $2.1 \mathrm{mg}$ of $\mathrm{Pd}_{2}(\mathrm{dba})_{3}$ ( $0.002 \mathrm{mmol}, 0.01$ equiv) and $4 \mathrm{~mL}$ of tBuOH . The mixture was degassed with 8 cycles of evacuation and back filled with nitrogen. The solution was heated to $110{ }^{\circ} \mathrm{C}$ for $20 \mathrm{~h}$. Once complete, the solution was passed through a pad of celite, and purified by column chromatography (eluting with $50 \% \mathrm{EtOAc/Hexanes).} \mathrm{The} \mathrm{solvent} \mathrm{was} \mathrm{removed} \mathrm{under} \mathrm{pressure} \mathrm{to}$ give a dark red solid, $120.0 \mathrm{mg}, 82 \%$ HPLC: $8.109 \mathrm{~min}$, Molecular Formula: $\mathrm{C}_{36} \mathrm{H}_{43} \mathrm{~N}_{7} \mathrm{O}_{5} \mathrm{Si}$, Mass Calc: $681.31 \mathrm{ESI}-\mathrm{MS}-F o u n d: 682$ [M+1], purity: $97 \%{ }^{1} \mathrm{HNMR}\left(700 \mathrm{MHz}, \mathrm{CDCl}_{3}\right.$-d) $\delta 11.03(\mathrm{~s}, 1 \mathrm{H})$, $8.84(\mathrm{~d}, \mathrm{~J}=8.4 \mathrm{~Hz}, 1 \mathrm{H}), 8.69(\mathrm{~s}, 1 \mathrm{H}), 7.55(\mathrm{~s}, 1 \mathrm{H}), 7.46(\mathrm{t}, \mathrm{J}=8.1 \mathrm{~Hz}, 1 \mathrm{H}), 7.42(\mathrm{~d}, \mathrm{~J}=7.8 \mathrm{~Hz}$, $1 \mathrm{H}), 7.33(\mathrm{dd}, \mathrm{J}=13.1,5.8 \mathrm{~Hz}, 4 \mathrm{H}), 7.31-7.27(\mathrm{~m}, 1 \mathrm{H}), 6.96-6.91(\mathrm{~m}, 2 \mathrm{H}), 6.82(\mathrm{q}, \mathrm{J}=8.5 \mathrm{~Hz}$, $2 \mathrm{H}), 6.59(\mathrm{~d}, \mathrm{~J}=3.7 \mathrm{~Hz}, 1 \mathrm{H}), 6.41(\mathrm{q}, \mathrm{J}=4.6 \mathrm{~Hz}, 1 \mathrm{H}), 5.49(\mathrm{~s}, 2 \mathrm{H}), 5.13(\mathrm{~s}, 2 \mathrm{H}), 4.33(\mathrm{~d}, \mathrm{~J}=5.7$ $\mathrm{Hz}, 2 \mathrm{H}), 3.90(\mathrm{~s}, 3 \mathrm{H}), 3.59-3.54(\mathrm{~m}, 2 \mathrm{H}), 2.96(\mathrm{~d}, \mathrm{~J}=4.8 \mathrm{~Hz}, 3 \mathrm{H}), 0.93(\mathrm{t}, \mathrm{J}=8.2 \mathrm{~Hz}, 2 \mathrm{H}),-0.09$ (s, 9H). ${ }^{13} \mathrm{CNMR}\left(176 \mathrm{MHz}, \mathrm{CDCl}_{3}\right) \delta 170.45,156.52,155.88,153.86,152.88,147.15,141.32$, 
$136.93,132.19,130.89,128.72,128.28,128.23,127.02,122.90,121.81,121.24,120.55,119.57$ $117.59,109.96,100.38,99.59,66.33,56.06,45.65,27.03,17.88,-1.21$.

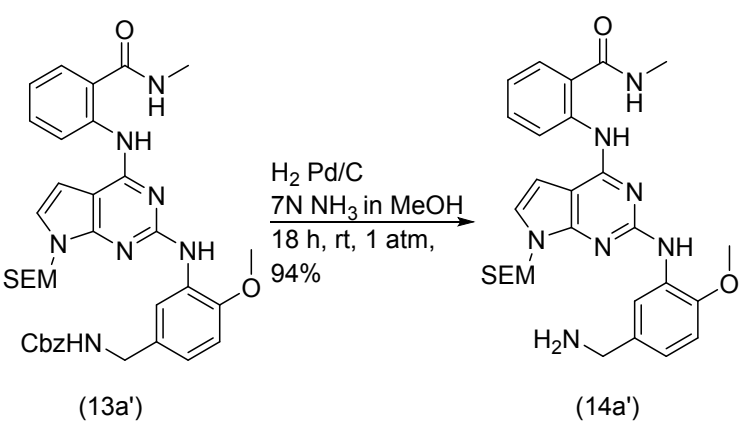

2-((2-((5-(aminomethyl)-2-methoxyphenyl)amino)-7-((2-(trimethylsilyl)ethoxy)methyl)-7Hpyrrolo[2,3-d]pyrimidin-4-yl)amino)-N-methylbenzamide (14a')

A dried flask was charged with $120 \mathrm{mg}$ of 13a' (0.176 mmol, 1.0 equiv) and $3 \mathrm{~mL}$ of $7 \mathrm{~N} \mathrm{NH}_{3}$ in $\mathrm{MeOH}$. The solution was degassed with three rounds of evacuation and back filled with nitrogen, and then RaNi (slurry in water), was added. The solution was further degassed by three cycles of evacuation and back fill with nitrogen. The atmosphere was replaced with hydrogen, and the mixture was stirred for 12 hours. Once complete, the atmosphere was removed and then solution was passed through a pad of celite. The solvent was removed to yield a green solid, $91.8 \mathrm{mg}$, 93.5\%. Molecular Formula: $\mathrm{C}_{28} \mathrm{H}_{37} \mathrm{~N}_{7} \mathrm{O}_{3} \mathrm{Si}$, Mass Calc: 547.27 ESI-MS-Found: 548 [M+1], HPLC: $6.241 \mathrm{~min}$, purity: 98.2\%. ${ }^{1} \mathrm{HNMR}(500 \mathrm{MHz}$, Chloroform-d) $\delta 10.61(\mathrm{~s}, 1 \mathrm{H}), 8.55-8.48$ $(\mathrm{m}, 1 \mathrm{H}), 8.44(\mathrm{~d}, \mathrm{~J}=8.0 \mathrm{~Hz}, 1 \mathrm{H}), 8.36(\mathrm{~s}, 1 \mathrm{H}), 7.56(\mathrm{~d}, \mathrm{~J}=10.3 \mathrm{~Hz}, 1 \mathrm{H}), 7.50(\mathrm{~s}, 1 \mathrm{H}), 7.42(\mathrm{~d}, \mathrm{~J}$ $=8.6 \mathrm{~Hz}, 1 \mathrm{H}), 7.10(\mathrm{~d}, \mathrm{~J}=7.5 \mathrm{~Hz}, 1 \mathrm{H}), 7.03(\mathrm{~s}, 1 \mathrm{H}), 7.01-6.96(\mathrm{~m}, 1 \mathrm{H}), 6.91(\mathrm{dd}, \mathrm{J}=10.3,7.4$ $\mathrm{Hz}, 2 \mathrm{H}), 6.80(\mathrm{~d}, \mathrm{~J}=8.1 \mathrm{~Hz}, 1 \mathrm{H}), 6.71(\mathrm{t}, \mathrm{J}=9.6 \mathrm{~Hz}, 1 \mathrm{H}), 6.47(\mathrm{~d}, \mathrm{~J}=9.9 \mathrm{~Hz}, 1 \mathrm{H}), 5.51(\mathrm{~s}, 2 \mathrm{H})$, $3.89-3.84(\mathrm{~m}, 3 \mathrm{H}), 3.55(\mathrm{t}, \mathrm{J}=8.4 \mathrm{~Hz}, 2 \mathrm{H}), 3.03-2.93(\mathrm{~m}, 3 \mathrm{H}), 0.96-0.89(\mathrm{~m}, 2 \mathrm{H}),-0.07(\mathrm{~d}, \mathrm{~J}$ $=2.7 \mathrm{~Hz}, 9 \mathrm{H}) .{ }^{13} \mathrm{CNMR}$ (176 MHz, cdcl3) $\delta 169.94,155.53,153.31,152.31,140.77,131.64$, $126.52,122.13,121.28,120.51,119.78,117.79,109.92,99.67,99.06,77.03,77.00,76.84,76.82$, 76.66, 76.64, 72.21, 65.78, 55.36, 26.43, 17.33, 13.86, -0.33, -1.75, -1.78. (126 MHz, cdcl3) $\delta$ 168.39, 167.61, 155.35, 153.84, 147.88, 144.63, 140.11, 133.00, 131.50, 130.70, 128.22, 121.92, $120.22,119.20,118.07,116.49,114.73,103.48,99.40,86.60,66.10,55.72,41.14,26.69,17.66$, -1.46 .

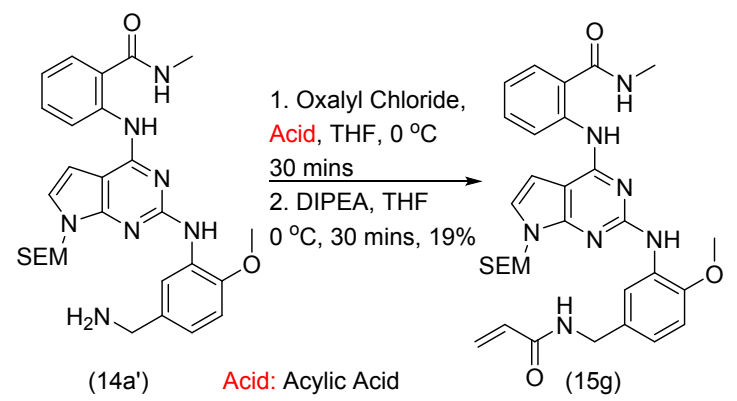

2-((2-((5-(acrylamidomethyl)-2-methoxyphenyl)amino)-7-((2-(trimethylsilyl)ethoxy)methyl)-7Hpyrrolo[2,3-d]pyrimidin-4-yl)amino)-N-methylbenzamide (15g)

Compound $15 \mathrm{~g}$ was synthesized using the protocol described for $15 \mathbf{a}$. Yields a light yellow residue, $13.9 \mathrm{mg}, 19 \%$. HPLC: $7.104 \mathrm{~min}$, Molecular Formula: $\mathrm{C}_{31} \mathrm{H}_{39} \mathrm{~N}_{7} \mathrm{O}_{4} \mathrm{Si}$, Mass Calc: 601.28 ESI-MS-Found: 602.2900 [M+1], purity: 74.4\%. ${ }^{1} \mathrm{HNMR}\left(700 \mathrm{MHz}, \mathrm{CDCl}_{3}\right) \delta 11.03(\mathrm{~s}, 1 \mathrm{H}), 8.81$ $(\mathrm{s}, 1 \mathrm{H}), 8.65(\mathrm{~s}, 1 \mathrm{H}), 7.50-7.45(\mathrm{~m}, 2 \mathrm{H}), 7.01(\mathrm{q}, \mathrm{J}=8.1,7.6 \mathrm{~Hz}, 1 \mathrm{H}), 6.93(\mathrm{t}, \mathrm{J}=3.7 \mathrm{~Hz}, 1 \mathrm{H})$, 
$6.85(\mathrm{~d}, \mathrm{~J}=8.5 \mathrm{~Hz}, 1 \mathrm{H}), 6.83(\mathrm{~d}, \mathrm{~J}=8.2 \mathrm{~Hz}, 1 \mathrm{H}), 6.60-6.55(\mathrm{~m}, 2 \mathrm{H}), 6.31(\mathrm{dd}, \mathrm{J}=3.0,1.8 \mathrm{~Hz}$, $1 \mathrm{H}), 6.28(\mathrm{dd}, \mathrm{J}=2.8,1.8 \mathrm{~Hz}, 1 \mathrm{H}), 5.66(\mathrm{dd}, \mathrm{J}=10.5,2.0 \mathrm{~Hz}, 1 \mathrm{H}), 5.62(\mathrm{dd}, \mathrm{J}=10.3,1.6 \mathrm{~Hz}, 1 \mathrm{H})$, $5.51(\mathrm{~s}, 2 \mathrm{H}), 4.44(\mathrm{dd}, \mathrm{J}=9.8,5.6 \mathrm{~Hz}, 2 \mathrm{H}), 3.91(\mathrm{~d}, \mathrm{~J}=2.7 \mathrm{~Hz}, 3 \mathrm{H}), 3.59-3.55(\mathrm{~m}, 2 \mathrm{H}), 3.01(\mathrm{~d}$, $\mathrm{J}=3.7 \mathrm{~Hz}, 3 \mathrm{H}), 0.96-0.89(\mathrm{~m}, 2 \mathrm{H}),-0.08(\mathrm{~d}, \mathrm{~J}=9.7 \mathrm{~Hz}, 9 \mathrm{H}) .{ }^{13} \mathrm{CNMR}(176 \mathrm{MHz}, \mathrm{cdcl} 3) \delta 170.30$, 165.28, 155.82, 153.81, 150.34, 147.14, 143.85, 132.16, 131.02, 130.18, 127.82, 127.71, 126.58, 122.87, 121.85, 119.99, 118.04, 117.18, 116.36, 110.04, 99.67, 86.17, 66.30, 56.00, 44.21, 27.00, -1.29 .

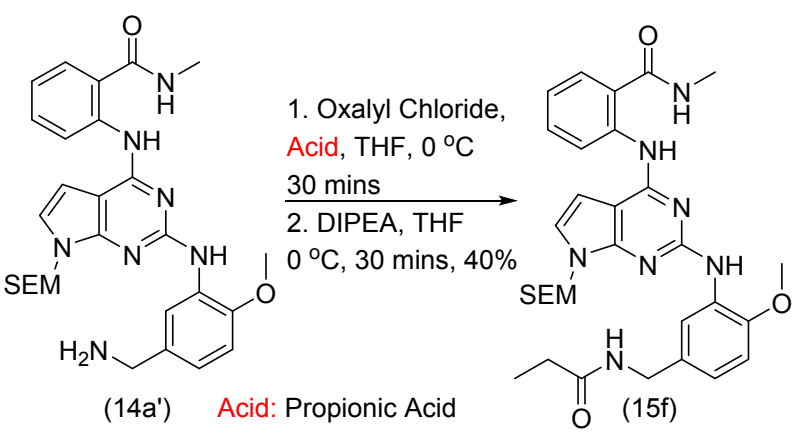

2-((2-((2-methoxy-5-(propionamidomethyl)phenyl)amino)-7-((2-(trimethylsilyl)ethoxy)methyl)-7Hpyrrolo[2,3-d]pyrimidin-4-yl)amino)-N-methylbenzamide (15f)

Compound $\mathbf{1 5 f}$ was synthesized using the protocol described for 15a. Yields aa light yellow residue,20 mg, 40\%. HPLC: $6.781 \mathrm{~min}$, Molecular Formula: $\mathrm{C}_{31} \mathrm{H}_{41} \mathrm{~N}_{7} \mathrm{O}_{4} \mathrm{Si}$, Mass Calc: 603.30 ESI-MS-Found: 603.3219 [M+1], purity: 99\% ${ }^{1} \mathrm{HNMR}(500 \mathrm{MHz}$, Chloroform-d) $\delta 11.13(\mathrm{~s}, 1 \mathrm{H})$, $8.88(\mathrm{~d}, \mathrm{~J}=8.4 \mathrm{~Hz}, 1 \mathrm{H}), 8.61(\mathrm{~d}, \mathrm{~J}=8.2 \mathrm{~Hz}, 1 \mathrm{H}), 7.99(\mathrm{~s}, 1 \mathrm{H}), 7.54(\mathrm{~s}, 1 \mathrm{H}), 7.50$ (d, J = $7.9 \mathrm{~Hz}$, $2 \mathrm{H}), 7.00(\mathrm{t}, \mathrm{J}=7.6 \mathrm{~Hz}, 1 \mathrm{H}), 6.94(\mathrm{~d}, \mathrm{~J}=3.6 \mathrm{~Hz}, 1 \mathrm{H}), 6.87(\mathrm{~d}, \mathrm{~J}=8.3 \mathrm{~Hz}, 1 \mathrm{H}), 6.82(\mathrm{~s}, 1 \mathrm{H}), 6.71$ $(\mathrm{d}, \mathrm{J}=8.0 \mathrm{~Hz}, 1 \mathrm{H}), 6.64(\mathrm{~d}, \mathrm{~J}=1.9 \mathrm{~Hz}, 1 \mathrm{H}), 6.62(\mathrm{~s}, 1 \mathrm{H}), 6.60(\mathrm{t}, \mathrm{J}=3.8 \mathrm{~Hz}, 2 \mathrm{H}), 6.53(\mathrm{~d}, \mathrm{~J}=5.7$ $\mathrm{Hz}, 1 \mathrm{H}), 5.53(\mathrm{~s}, 2 \mathrm{H}), 4.28(\mathrm{~d}, \mathrm{~J}=5.5 \mathrm{~Hz}, 3 \mathrm{H}), 3.91(\mathrm{~s}, 3 \mathrm{H}), 3.59(\mathrm{t}, \mathrm{J}=8.2 \mathrm{~Hz}, 2 \mathrm{H}), 3.01(\mathrm{~d}, \mathrm{~J}=$ $4.7 \mathrm{~Hz}, 3 \mathrm{H}), 2.80(\mathrm{~s}, 2 \mathrm{H}), 2.24(\mathrm{dq}, \mathrm{J}=18.6,7.6 \mathrm{~Hz}, 2 \mathrm{H}), 1.18(\mathrm{dt}, \mathrm{J}=15.0,7.6 \mathrm{~Hz}, 3 \mathrm{H}), 0.94(\mathrm{t}$, $\mathrm{J}=8.2 \mathrm{~Hz}, 2 \mathrm{H}),-0.07(\mathrm{~s}, 9 \mathrm{H}) .{ }^{13} \mathrm{CNMR}(126 \mathrm{MHz}$, cdcl3) $\delta 173.53,170.13,162.56,153.57,152.35$, $147.76,146.72,140.95,136.35,132.00,130.94,130.38,129.69,126.73,122.55,121.67,121.03$, $120.14,118.19,117.76,114.49,110.29,109.65,100.00,99.45,72.58,66.11,55.52,43.36,26.78$, $17.64,9.83,-1.49$.

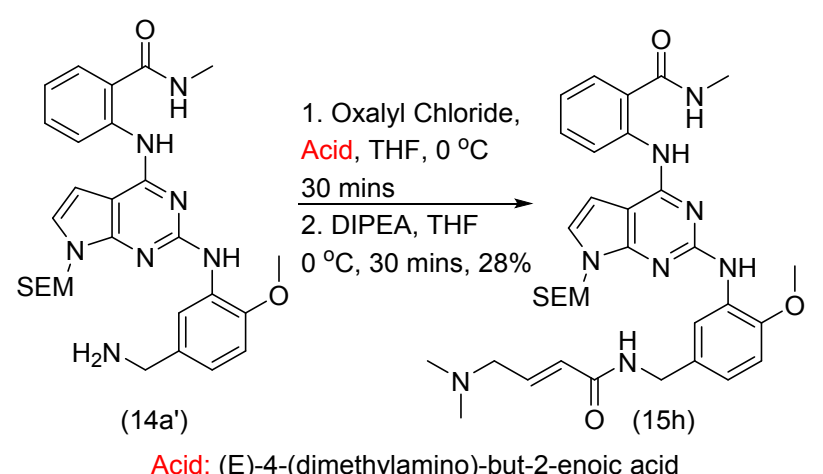

(E)-2-((2-((5-((4-(dimethylamino)but-2-enamido)methyl)-2-methoxyphenyl)amino)-7-((2(trimethylsilyl)ethoxy)methyl)-7H-pyrrolo[2,3-d]pyrimidin-4-yl)amino)-N-methylbenzamide (15h) Compound $15 \mathrm{~h}$ was synthesized using the protocol described for 15a. Yields a light yellow residue, 20 mg, 28\%. HPLC: 7.65 min, Molecular Formula: $\mathrm{C}_{34} \mathrm{H}_{46} \mathrm{~N}_{8} \mathrm{O}_{4} \mathrm{Si}$, Mass Calc: 658.34 ESIMS-Found: 662 [M+4], purity: 85\%. ${ }^{1} \mathrm{HNMR}(700 \mathrm{MHz}$, Chloroform-d) $\delta 10.87(\mathrm{~s}, 1 \mathrm{H}), 8.78$ (d, J 
$=8.3 \mathrm{~Hz}, 1 \mathrm{H}), 8.70-8.65(\mathrm{~m}, 1 \mathrm{H}), 7.57(\mathrm{~s}, 1 \mathrm{H}), 7.49(\mathrm{~d}, \mathrm{~J}=7.7 \mathrm{~Hz}, 2 \mathrm{H}), 7.23(\mathrm{~d}, \mathrm{~J}=6.5 \mathrm{~Hz}, 1 \mathrm{H})$, $7.03(\mathrm{t}, \mathrm{J}=7.6 \mathrm{~Hz}, 1 \mathrm{H}), 6.96(\mathrm{~d}, \mathrm{~J}=3.6 \mathrm{~Hz}, 1 \mathrm{H}), 6.85(\mathrm{~d}, \mathrm{~J}=3.0 \mathrm{~Hz}, 2 \mathrm{H}), 6.60(\mathrm{~d}, \mathrm{~J}=3.5 \mathrm{~Hz}, 1 \mathrm{H})$, $6.44(\mathrm{~d}, \mathrm{~J}=5.5 \mathrm{~Hz}, 1 \mathrm{H}), 5.54(\mathrm{~s}, 2 \mathrm{H}), 4.40(\mathrm{~d}, \mathrm{~J}=5.8 \mathrm{~Hz}, 2 \mathrm{H}), 3.93(\mathrm{~s}, 3 \mathrm{H}), 3.60-3.55(\mathrm{~m}, 2 \mathrm{H})$, $3.03(\mathrm{~d}, \mathrm{~J}=4.8 \mathrm{~Hz}, 3 \mathrm{H}), 0.94$ (ddd, $\mathrm{J}=10.9,7.6,3.2 \mathrm{~Hz}, 2 \mathrm{H}),-0.08(\mathrm{~s}, 9 \mathrm{H}) .{ }^{13} \mathrm{CNMR}(176 \mathrm{MHz}$, cdcl3) $\delta$ 169.99, 160.06, 156.21, 155.36, 153.45, 152.51, 146.93, 140.68, 131.63, 130.59, 128.68, 126.62, 122.54, 121.86, 120.99, 120.81, 119.65, 117.58, 109.60, 99.95, 99.16, 65.90, 55.63, $44.10,26.61,21.35,17.43,-1.66$.

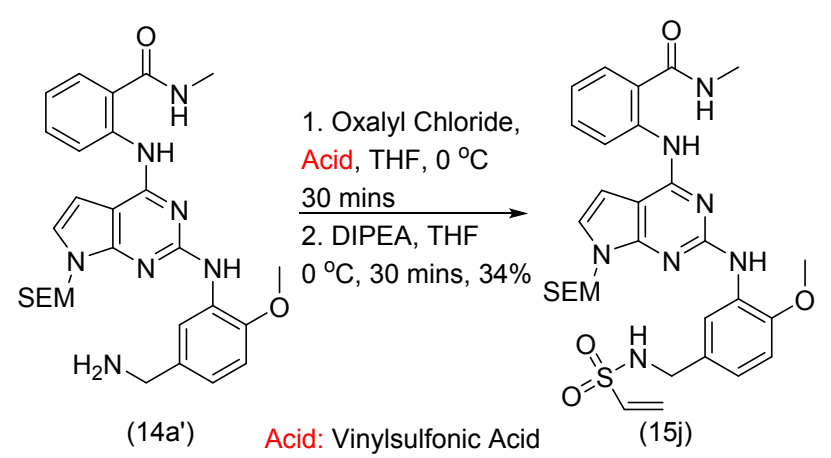

2-((2-((2-methoxy-5-(vinylsulfonamidomethyl)phenyl)amino)-7-((2-(trimethylsilyl)ethoxy)methyl)7H-pyrrolo[2,3-d]pyrimidin-4-yl)amino)-N-methylbenzamide (15j)

Compound 15j was synthesized using the protocol described for 15a. Yields a light yellow residue, $10 \mathrm{mg}, 34 \%$. HPLC: $7.534 \mathrm{~min}$, Molecular Formula: $\mathrm{C}_{30} \mathrm{H}_{39} \mathrm{~N}_{7} \mathrm{O}_{5} \mathrm{SSi}$, Mass Calc: $637.25 \mathrm{ESI}-$ MS-Found: $638[\mathrm{M}+1]$, purity: $85 \%$. ${ }^{1} \mathrm{HNMR}(400 \mathrm{MHz}$, Chloroform-d) $\delta 8.37(\mathrm{~s}, 1 \mathrm{H}), 8.04(\mathrm{~s}, 1 \mathrm{H})$, $7.50(\mathrm{~s}, 1 \mathrm{H}), 6.89(\mathrm{~s}, 3 \mathrm{H}), 6.50(\mathrm{~s}, 1 \mathrm{H}), 6.22(\mathrm{~s}, 1 \mathrm{H}), 5.91(\mathrm{~s}, 1 \mathrm{H}), 5.57(\mathrm{~s}, 2 \mathrm{H}), 4.23(\mathrm{~m}, 2 \mathrm{H}), 3.95$ (s, 3H), $3.61(\mathrm{~s}, 2 \mathrm{H}), 3.37(\mathrm{~d}, J=16.6 \mathrm{~Hz}, 2 \mathrm{H}), 2.96-2.81(\mathrm{~m}, 3 \mathrm{H}), 0.88(\mathrm{~d}, J=24.2 \mathrm{~Hz}, 2 \mathrm{H})$, 0.07 (s, 9H). ${ }^{13} \mathrm{CNMR}(176 \mathrm{MHz}, \mathrm{cdcl} 3) \delta$ 169.98, 165.69, 155.06, 150.31, 147.80, 143.19, 135.08, 133.85, 131.70, 128.59, 122.86, 121.52, 120.55, 118.62, 117.86, 116.77, 115.07, 110.45, 103.85, $100.40,74.30,68.65,55.73,44.36,25.17,22.46,17.58,-1.56$.

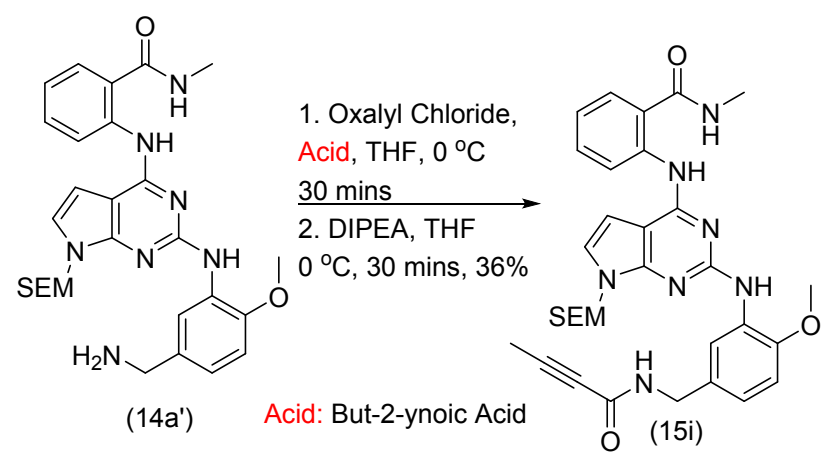

2-((2-((5-(but-2-ynamidomethyl)-2-methoxyphenyl)amino)-7-((2-(trimethylsilyl)ethoxy)methyl)7H-pyrrolo[2,3-d]pyrimidin-4-yl)amino)-N-methylbenzamide (15i)

Compound 15i was synthesized using the protocol described for 15a. Yields a light yellow residue, 10 mg, 36\%. HPLC: 8.610 min, Molecular Formula: $\mathrm{C}_{32} \mathrm{H}_{39} \mathrm{~N}_{7} \mathrm{O}_{4} \mathrm{Si}$, Mass Calc: $613.28 \mathrm{ESI}-$ MS-Found: 623, purity: 65\%. ${ }^{1} \mathrm{HNMR}(500 \mathrm{MHz}$, Chloroform-d) $\delta 11.10(\mathrm{~s}, 1 \mathrm{H}), 8.92$ (d, J = 8.4 $\mathrm{Hz}, 1 \mathrm{H}), 8.65(\mathrm{~d}, \mathrm{~J}=8.3 \mathrm{~Hz}, 1 \mathrm{H}), 7.52(\mathrm{~d}, \mathrm{~J}=7.1 \mathrm{~Hz}, 1 \mathrm{H}), 7.49(\mathrm{~d}, \mathrm{~J}=8.2 \mathrm{~Hz}, 1 \mathrm{H}), 7.02(\mathrm{t}, \mathrm{J}=$ $7.7 \mathrm{~Hz}, 1 \mathrm{H}), 6.95(\mathrm{~d}, \mathrm{~J}=3.6 \mathrm{~Hz}, 1 \mathrm{H}), 6.88(\mathrm{~d}, \mathrm{~J}=8.4 \mathrm{~Hz}, 1 \mathrm{H}), 6.83(\mathrm{~s}, 1 \mathrm{H}), 6.72(\mathrm{~d}, \mathrm{~J}=8.2 \mathrm{~Hz}$, $1 \mathrm{H}), 6.65(\mathrm{~d}, \mathrm{~J}=2.0 \mathrm{~Hz}, 1 \mathrm{H}), 6.63(\mathrm{~d}, \mathrm{~J}=2.3 \mathrm{~Hz}, 1 \mathrm{H}), 6.62-6.60(\mathrm{~m}, 2 \mathrm{H}), 5.55(\mathrm{~d}, \mathrm{~J}=7.9 \mathrm{~Hz}$, $2 \mathrm{H}), 4.32(\mathrm{~d}, \mathrm{~J}=5.7 \mathrm{~Hz}, 3 \mathrm{H}), 3.93(\mathrm{~s}, 2 \mathrm{H}), 3.60(\mathrm{t}, \mathrm{J}=8.1 \mathrm{~Hz}, 2 \mathrm{H}), 3.03(\mathrm{~d}, \mathrm{~J}=4.7 \mathrm{~Hz}, 3 \mathrm{H}), 1.93$ 
(s, 4H), 0.95 (t, J = 8.1 Hz, 2H), $-0.06(\mathrm{~d}, \mathrm{~J}=4.0 \mathrm{~Hz}, 9 \mathrm{H}) .{ }^{13} \mathrm{CNMR}(126 \mathrm{MHz}, \mathrm{cdcl} 3) \delta 170.42$, 155.90, 153.88, 153.48, 152.86, 148.01, 147.13, 141.38, 136.74, 132.34, 130.24, 129.42, 126.86, $122.79,121.95,121.19,120.60,120.30,118.34,118.09,114.70,110.58,109.93,100.33,99.66$, $83.71,72.81,66.38,55.81,43.86,27.07,17.92,3.86,-1.21$.

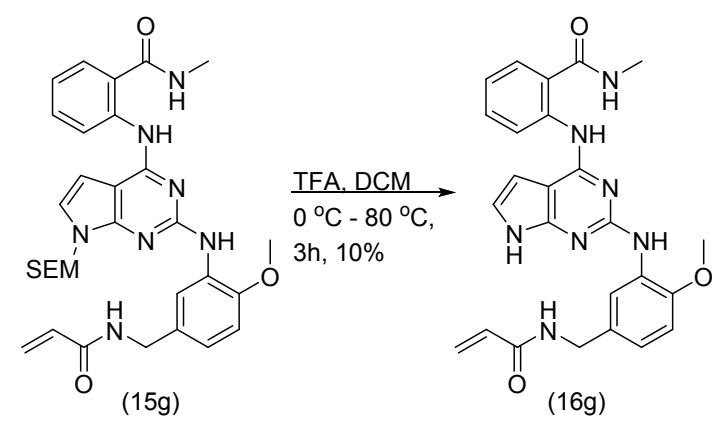

2-((2-((5-(acrylamidomethyl)-2-methoxyphenyl)amino)-7-((2-(trimethylsilyl)ethoxy)methyl)-7Hpyrrolo[2,3-d]pyrimidin-4-yl)amino)-N-methylbenzamide (16g)

Compound $\mathbf{1 6 g}$ was synthesized using the protocol described for $\mathbf{1 6 b}$. Yields a light yellow solid, 2 mg, 10\%. HPLC: 5.114 min, Molecular Formula: $\mathrm{C}_{25} \mathrm{H}_{25} \mathrm{~N}_{7} \mathrm{O}_{3}$, Mass Calc: 471.20 ESI-MSFound: 471 [M], purity: 90\%. ${ }^{1} \mathrm{HNMR}(700 \mathrm{MHz}$, DMSO-d6) $\delta 11.70$ (s, 1H), 8.80 (dd, J = 8.0, 3.3 $\mathrm{Hz}, 1 \mathrm{H}), 8.75(\mathrm{t}, \mathrm{J}=4.6 \mathrm{~Hz}, 1 \mathrm{H}), 8.57(\mathrm{t}, \mathrm{J}=6.0 \mathrm{~Hz}, 1 \mathrm{H}), 8.40(\mathrm{~d}, \mathrm{~J}=2.1 \mathrm{~Hz}, 1 \mathrm{H}), 7.76(\mathrm{dd}, \mathrm{J}=$ 8.0, $1.5 \mathrm{~Hz}, 1 \mathrm{H}), 7.63(\mathrm{~d}, \mathrm{~J}=3.9 \mathrm{~Hz}, 1 \mathrm{H}), 7.52-7.49(\mathrm{~m}, 1 \mathrm{H}), 7.16(\mathrm{~d}, \mathrm{~J}=3.5 \mathrm{~Hz}, 1 \mathrm{H}), 7.06(\mathrm{t}, \mathrm{J}$ $=7.6 \mathrm{~Hz}, 1 \mathrm{H}), 6.99(\mathrm{~d}, \mathrm{~J}=4.5 \mathrm{~Hz}, 1 \mathrm{H}), 6.87-6.83(\mathrm{~m}, 1 \mathrm{H}), 6.51(\mathrm{t}, \mathrm{J}=7.3 \mathrm{~Hz}, 1 \mathrm{H}), 6.40(\mathrm{~d}, \mathrm{~J}=$ $3.6 \mathrm{~Hz}, 1 \mathrm{H}$ ), 5.60 (ddd, J = 10.3, 4.3, $2.1 \mathrm{~Hz}, 1 \mathrm{H}), 4.31(\mathrm{~d}, \mathrm{~J}=6.0 \mathrm{~Hz}, 2 \mathrm{H}), 3.87(\mathrm{~d}, \mathrm{~J}=2.5 \mathrm{~Hz}$, $3 \mathrm{H}), 2.82(\mathrm{~d}, \mathrm{~J}=4.5 \mathrm{~Hz}, 3 \mathrm{H}) .{ }^{13} \mathrm{CNMR}(176 \mathrm{MHz}, \mathrm{dmso}) \delta$ 169.63, 167.25, 164.75, 155.43, 153.21, $147.32,143.98,134.27,132.08,131.91,128.25,125.52,121.04,120.71,119.73,118.62,117.83$, $116.41,110.45,99.58,90.85,56.10,42.56,26.55$

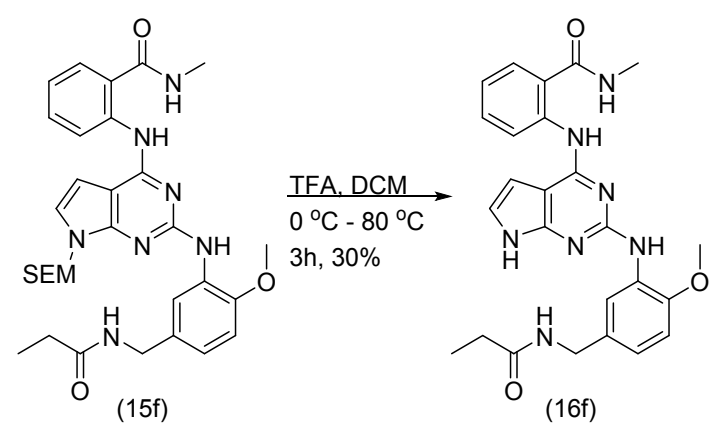

2-((2-((2-methoxy-5-(propionamidomethyl)phenyl)amino)-7-((2-(trimethylsilyl)ethoxy)methyl)-7Hpyrrolo[2,3-d]pyrimidin-4-yl)amino)-N-methylbenzamide (16f)

Compound $16 \mathrm{f}$ was synthesized using the protocol described for $16 \mathrm{~b}$. Yields a light yellow residue, $5 \mathrm{mg}, 30 \%$. HPLC: $4.99 \mathrm{~min}$, Molecular Formula: $\mathrm{C}_{25} \mathrm{H}_{27} \mathrm{~N}_{7} \mathrm{O}_{3}$, Mass Calc: $473.22 \mathrm{ESI}-$ MS-Found: 474 [M+1], purity: $95 \%{ }^{1} \mathrm{HNMR}(700 \mathrm{MHz}, \mathrm{DMSO}-\mathrm{d} 6) \delta 11.64(\mathrm{~s}, 1 \mathrm{H}), 11.37(\mathrm{~s}, 1 \mathrm{H})$, $8.85(\mathrm{~d}, \mathrm{~J}=8.6 \mathrm{~Hz}, 1 \mathrm{H}), 8.74(\mathrm{~s}, 1 \mathrm{H}), 8.26-8.19(\mathrm{~m}, 2 \mathrm{H}), 8.11-8.04(\mathrm{~m}, 2 \mathrm{H}), 7.75(\mathrm{~d}, \mathrm{~J}=8.1$ $\mathrm{Hz}, 1 \mathrm{H}), 7.53(\mathrm{~s}, 1 \mathrm{H}), 7.50-7.44(\mathrm{~m}, 1 \mathrm{H}), 7.08-7.03(\mathrm{~m}, 1 \mathrm{H}), 7.03-6.98(\mathrm{~m}, 1 \mathrm{H}), 6.93(\mathrm{~s}, 1 \mathrm{H})$, $6.82(\mathrm{~d}, \mathrm{~J}=8.4 \mathrm{~Hz}, 1 \mathrm{H}), 4.24(\mathrm{~d}, \mathrm{~J}=6.6 \mathrm{~Hz}, 2 \mathrm{H}), 3.86(\mathrm{~d}, \mathrm{~J}=5.5 \mathrm{~Hz}, 3 \mathrm{H}), 2.83(\mathrm{~d}, \mathrm{~J}=4.6 \mathrm{~Hz}$, $3 \mathrm{H}), 2.16(\mathrm{q}, \mathrm{J}=7.7 \mathrm{~Hz}, 2 \mathrm{H}), 1.05(\mathrm{t}, \mathrm{J}=7.6 \mathrm{~Hz}, 3 \mathrm{H}) .{ }^{13} \mathrm{CNMR}(176 \mathrm{MHz}, \mathrm{dmso}) \delta 172.87,169.81$, 163.15, 161.80, 159.33, 155.89, 153.30, 152.61, 148.82, 145.71, 141.27, 137.80, 133.24, 132.28, 
$128.79,128.34,120.96,119.90,119.67,119.40,115.42,113.37,110.68,99.47,97.73,55.73$, $42.24,28.85,26.69,10.39$.

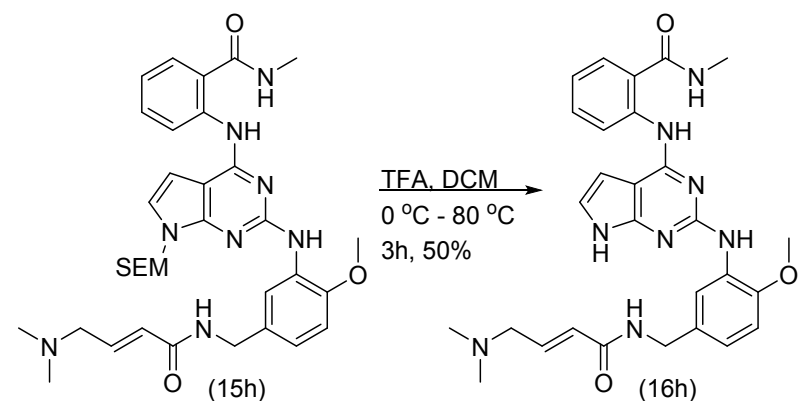

(E)-2-((2-((5-)(4-(dimethylamino)but-2-enamido)methyl)-2-methoxyphenyl)amino)-7-((2-

(trimethylsilyl)ethoxy)methyl)-7H-pyrrolo[2,3-d]pyrimidin-4-yl)amino)-N-methylbenzamide (16h) Compound 16h synthesized using the protocol described for $16 \mathrm{~b}$. Yields a bright yellow solid, 8 mg, 50\%. HPLC: 5.485 min, Molecular Formula: $\mathrm{C}_{28} \mathrm{H}_{32} \mathrm{~N}_{8} \mathrm{O}_{3}$, Mass Calc: 528.26 ESI-MS-Found: $562[\mathrm{M}+\mathrm{H}+\mathrm{MeOH}]$, purity: $95 \%$. ${ }^{1} \mathrm{HNMR}(700 \mathrm{MHz}, \mathrm{DMSO}-\mathrm{d} 6) \delta 11.71(\mathrm{~s}, 1 \mathrm{H}), 9.34(\mathrm{t}, \mathrm{J}=6.3$ $\mathrm{Hz}, 1 \mathrm{H}), 8.80(\mathrm{~d}, \mathrm{~J}=8.4 \mathrm{~Hz}, 1 \mathrm{H}), 8.78-8.71(\mathrm{~m}, 1 \mathrm{H}), 8.39-8.36(\mathrm{~m}, 1 \mathrm{H}), 7.76(\mathrm{dd}, \mathrm{J}=7.9,1.6$ $\mathrm{Hz}, 1 \mathrm{H}), 7.64(\mathrm{~s}, 1 \mathrm{H}), 7.53-7.48(\mathrm{~m}, 1 \mathrm{H}), 7.16(\mathrm{~d}, \mathrm{~J}=3.5 \mathrm{~Hz}, 1 \mathrm{H}), 7.08-7.04(\mathrm{~m}, 1 \mathrm{H}), 6.99(\mathrm{~d}$, $\mathrm{J}=8.3 \mathrm{~Hz}, 1 \mathrm{H}), 6.86(\mathrm{dd}, \mathrm{J}=8.2,2.2 \mathrm{~Hz}, 1 \mathrm{H}), 6.42(\mathrm{t}, \mathrm{J}=7.3 \mathrm{~Hz}, 1 \mathrm{H}), 6.40(\mathrm{~d}, \mathrm{~J}=3.6 \mathrm{~Hz}, 1 \mathrm{H})$, $5.48(\mathrm{~d}, \mathrm{~J}=7.2 \mathrm{~Hz}, 2 \mathrm{H}), 4.29$ (d, J = 6.3 Hz, 2H), 3.87 (s, 3H), 2.83 (d, J = 4.4 Hz, 3H), 1.26 (dd, $\mathrm{J}=6.3,3.7 \mathrm{~Hz}, 6 \mathrm{H}) .{ }^{13} \mathrm{CNMR}(176 \mathrm{MHz}, \mathrm{dmso}) \delta 169.63,160.56,157.59,155.46,153.20,147.55$, $143.59,140.93,132.65,132.09,130.54,128.22,123.46,121.00,120.71,119.67,118.96,118.06$, $116.65,114.47,110.47,99.57,97.95,66.48,56.07,42.76,41.57,26.54$.
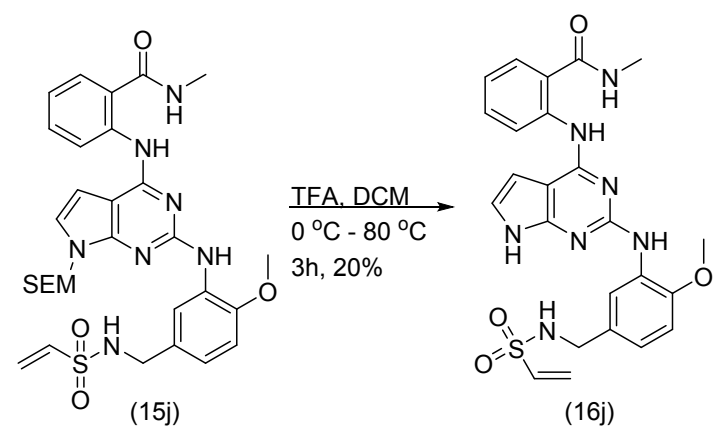

2-((2-((2-methoxy-5-(vinylsulfonamidomethyl)phenyl)amino)-7H-pyrrolo[2, 3-d]pyrimidin-4yl)amino)-N-methylbenzamide (16j)

Compound 16j was synthesized using the protocol described for $16 \mathbf{a}$. Yields a white residue, 2 mg, 20\%. HPLC: 6.13 min, Molecular Formula: $\mathrm{C}_{24} \mathrm{H}_{25} \mathrm{~N}_{7} \mathrm{O}_{4} \mathrm{~S}$, Mass Calc: 507.17 ESI-MS-Found: 508 [M+1], purity: 95\%. ${ }^{1} \mathrm{HNMR}(700 \mathrm{MHz}$, Chloroform-d) $\delta 10.82(\mathrm{~s}, 1 \mathrm{H}), 8.63(\mathrm{~s}, 1 \mathrm{H}), 8.51(\mathrm{~s}$, $1 \mathrm{H}), 7.58(\mathrm{~s}, 1 \mathrm{H}), 7.53(\mathrm{~s}, 1 \mathrm{H}), 7.47(\mathrm{~s}, 1 \mathrm{H}), 6.92(\mathrm{~s}, 1 \mathrm{H}), 6.83(\mathrm{~s}, 1 \mathrm{H}), 6.58(\mathrm{~s}, 1 \mathrm{H}), 5.81(\mathrm{~s}, 1 \mathrm{H})$, $4.17-4.07(\mathrm{~m}, 2 \mathrm{H}), 3.92(\mathrm{~s}, 3 \mathrm{H}), 3.03(\mathrm{~s}, 3 \mathrm{H}) .{ }^{13} \mathrm{CNMR}(176 \mathrm{MHz}, \mathrm{cdcl} 3) \delta$ 169.98, 165.69, $155.06,150.31,147.80,143.19,135.08,133.85,131.70,128.59,122.86,121.52,120.55,118.62$, 117.86, 116.77, 115.07, 110.45, 103.85, 100.40, 55.73, 44.36, 25.17. 


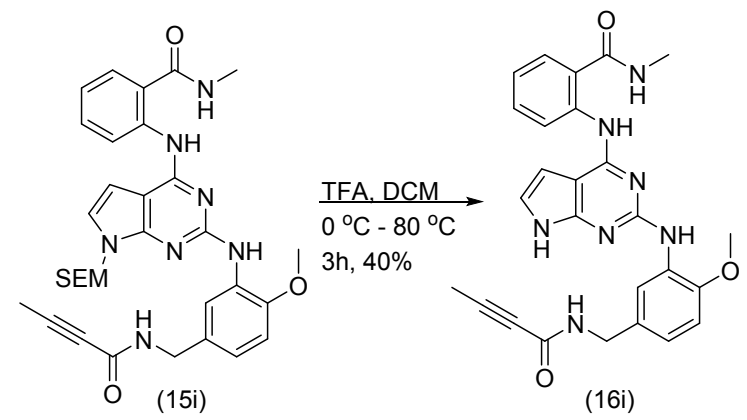

2-((2-((5-(but-2-ynamidomethyl)-2-methoxyphenyl)amino)-7H-pyrrolo[2, 3-d]pyrimidin-4yl)amino)-N-methylbenzamide (16i)

Compound 16i was synthesized using the protocol described for 16b. Yields a white residue, 4 mg, 40\%. HPLC: 5.67 min, Molecular Formula: $\mathrm{C}_{26} \mathrm{H}_{25} \mathrm{~N}_{7} \mathrm{O}_{3}$, Mass Calc: 483.20 ESI-MS-Found: 484 [M+1], 506 [M+Na], purity: 92\% 1H NMR (700 MHz, DMSO-d6) $\delta 12.05$ (s, 1H), 11.68 (s, $1 \mathrm{H}), 8.96(\mathrm{~s}, 1 \mathrm{H}), 8.83(\mathrm{~s}, 3 \mathrm{H}), 8.74(\mathrm{~s}, 1 \mathrm{H}), 8.62(\mathrm{~d}, \mathrm{~J}=8.1 \mathrm{~Hz}, 1 \mathrm{H}), 8.28(\mathrm{~s}, 1 \mathrm{H}), 7.75(\mathrm{~s}, 1 \mathrm{H})$, $7.61(\mathrm{~s}, 1 \mathrm{H}), 7.51(\mathrm{t}, \mathrm{J}=3.4 \mathrm{~Hz}, 1 \mathrm{H}), 7.07(\mathrm{~s}, 2 \mathrm{H}), 6.94(\mathrm{~s}, 1 \mathrm{H}), 4.25(\mathrm{~d}, \mathrm{~J}=5.8 \mathrm{~Hz}, 2 \mathrm{H}), 3.86(\mathrm{~d}$, $\mathrm{J}=3.4 \mathrm{~Hz}, 3 \mathrm{H}), 2.84-2.80(\mathrm{~m}, 7 \mathrm{H}), 1.95-1.94(\mathrm{~m}, 12 \mathrm{H}) .{ }^{13} \mathrm{CNMR}(176 \mathrm{MHz}, \mathrm{dmso}) \delta 162.92$, 162.46, 161.19, 156.25, 152.67, 147.87, 145.77, 137.82, 134.02, 131.84, 131.51, 127.00, 122.23, $121.19,121.07,119.79,119.58,118.60,116.58,115.41,113.24,110.65,55.73,42.37,26.70$, 3.40 .<smiles>COc1ccc(C(N)=O)cc1N</smiles>

(18) $\underset{65^{\circ} \mathrm{C}, 6-8 \mathrm{~h}}{\stackrel{\mathrm{LiAlH}_{4}, \mathrm{THF}}{\longrightarrow}}$ quant.<smiles>COc1ccc(CN)cc1N</smiles>

(19)

5-(aminomethyl)-2-methoxyaniline (19)

A flame dried flask was charged with $995.4 \mathrm{mg}$ of 3-amino-4-methoxybenzamide (18) $(6 \mathrm{mmol}$, 1.0 equiv) and $30 \mathrm{~mL}$ of dry THF ( 0.1 molar). The solution was cooled to $0{ }^{\circ} \mathrm{C}$ and $6.1 \mathrm{~mL}$ of LAH (10 mmol, 2 equiv) were added dropwise over $5 \mathrm{~min}$. The bright yellow solution was allowed to continue stirring at $0{ }^{\circ} \mathrm{C}$ for $30 \mathrm{~min}$. After $30 \mathrm{~min}$, the solution was warmed to $65^{\circ} \mathrm{C}$ for $6-8$ hours. Once complete, the reaction was cooled back to $0{ }^{\circ} \mathrm{C}$ and worked up with the Feiser Method: $0.457 \mathrm{~mL}$ water, followed by $0.457 \mathrm{~mL}$ of freshly prepared $15 \% \mathrm{NaOH}$, and $1.371 \mathrm{~mL}$ of water. The resultant brown solution was allowed to stir at rt for $15 \mathrm{~min}$. Then $\mathrm{MgSO}_{4}$ was added and the solution was allowed to stir for additional $15 \mathrm{~min}$. The $\mathrm{MgSO}_{4}$ was filtered off and the solvent was removed to yield a yellow oil, $0.900 \mathrm{~g}, 100 \%$. Molecular Formula: $\mathrm{C}_{8} \mathrm{H}_{12} \mathrm{~N}_{2} \mathrm{O}$, Mass Calc: 152.09 ESI-MS-Found: 152 [M] HPLC: 0.96 min, purity: > 95\% ${ }^{1 H N M R ~(400 ~ M H z, ~ D M S O-d 6) ~ \delta ~} 6.69$ (d, $J=8.1 \mathrm{~Hz}, 1 \mathrm{H}), 6.59(\mathrm{~d}, J=2.1 \mathrm{~Hz}, 1 \mathrm{H}), 6.46(\mathrm{dd}, J=8.1,2.1 \mathrm{~Hz}, 1 \mathrm{H}), 4.59(\mathrm{~s}, 2 \mathrm{H}), 3.72(\mathrm{~s}, 3 \mathrm{H})$, $3.52(\mathrm{~s}, 2 \mathrm{H}), 1.63(\mathrm{~s}, 2 \mathrm{H})$. 
<smiles>COc1ccc(CN)cc1N</smiles>

(19)<smiles>COc1ccc(CNC(=O)CCC(F)(F)F)cc1N</smiles>

benzyl (3-amino-4-methoxybenzyl)carbamate (17)

A flame dried flask was charged with $900.0 \mathrm{mg}$ of $18(5.91 \mathrm{mmol}, 1.0$ equiv) and $40 \mathrm{~mL}$ of dry THF (0.19 molar). The solution was cooled to $0{ }^{\circ} \mathrm{C}$ and $0.92 \mathrm{~mL}$ of TEA (6.6 mmol, 1.1 equiv), and $0.94 \mathrm{~mL}$ of $\mathrm{Cbz}-\mathrm{Cl}(6.6 \mathrm{mmol}, 1.1$ equiv) were added in one portion, respectively. Once complete, the reaction was quenched with water and then extracted with EtOAc $(3 \times 50 \mathrm{~mL})$. The combined organic layers were washed with brine $(1 \times 30 \mathrm{~mL})$ and then dried over $\mathrm{Na}_{2} \mathrm{SO}_{4}$. The crude oil was purified by column chromatography $(0-100 \% \mathrm{EtOAc} / \mathrm{Hex})$ to give a light yellow oil, $1.14 \mathrm{~g}, 67.3 \%$. HPLC: $4.871 \mathrm{~min}$, Molecular Formula: $\mathrm{C}_{16} \mathrm{H}_{18} \mathrm{~N}_{2} \mathrm{O}_{3}$ Mass Calc: $286.13 \mathrm{ESI}-\mathrm{MS}-$ Found: 287, purity: $85 \%$ 1HNMR (500 MHz, Chloroform-d) $\delta 7.34$ (dd, J = 21.0, $4.5 \mathrm{~Hz}, 5 \mathrm{H}), 6.72$ $(\mathrm{d}, \mathrm{J}=8.1 \mathrm{~Hz}, 1 \mathrm{H}), 6.65(\mathrm{~s}, 1 \mathrm{H}), 6.62(\mathrm{~d}, \mathrm{~J}=7.8 \mathrm{~Hz}, 1 \mathrm{H}), 5.13(\mathrm{~s}, 2 \mathrm{H}), 4.25(\mathrm{~d}, \mathrm{~J}=5.9 \mathrm{~Hz}, 2 \mathrm{H})$, $3.83(\mathrm{~s}, 3 \mathrm{H}), 3.79(\mathrm{~s}, 2 \mathrm{H})$. 

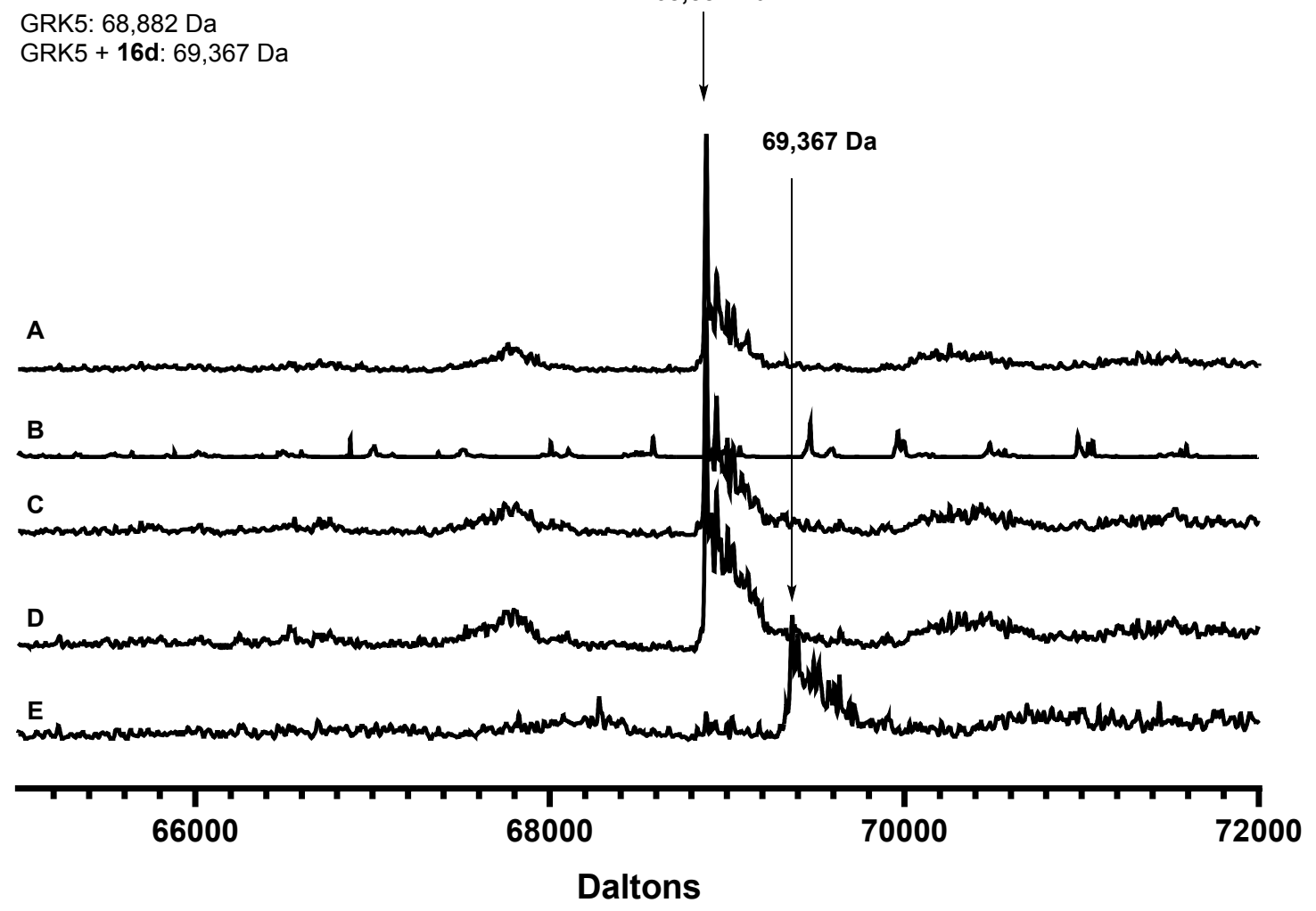

Figure S1. Intact protein MS of GRK5 incubated with 16b-e. (A) MS trace for hGRK5 shows the predicted weight of 68,882 Da. (B) MS trace GRK5 incubated with 16b, shows that only a small portion of compound labels GRK5. (C) MS trace for GRK5 incubated with 16c indicating no covalent interaction. (D) MS trace for GRK5 incubated with 16e indicating no covalent interaction. (E) MS trace for GRK5 incubated with 16d indicating that covalent interaction has taken place, with the predicted adduct appearing at 69,367 Da. 


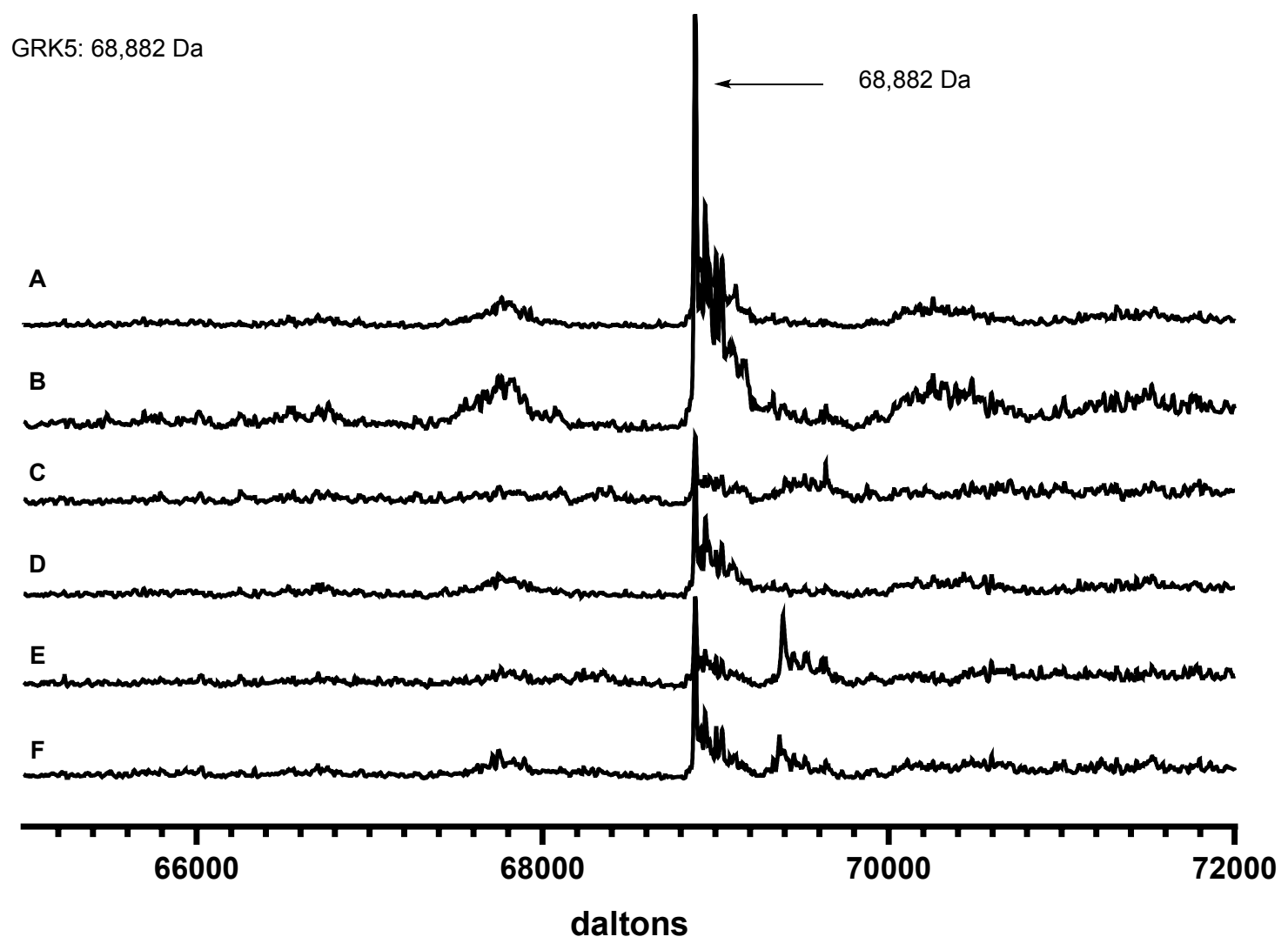

Figure S2. Intact protein MS of GRK5 incubated with 16f-j. (A) MS trace for hGRK5shows the predicted weight of $68,882 \mathrm{Da}$. (B) MS trace GRK5 incubated with 16f. (C) MS trace for GRK5 incubated with 16g. (D) MS trace for GRK5 incubated with 16h. (E) MS trace for GRK5 incubated with 16i. (F) MS trace for GRK5 incubated with 16j. None showed strong evidence for covalent adduct formation. 


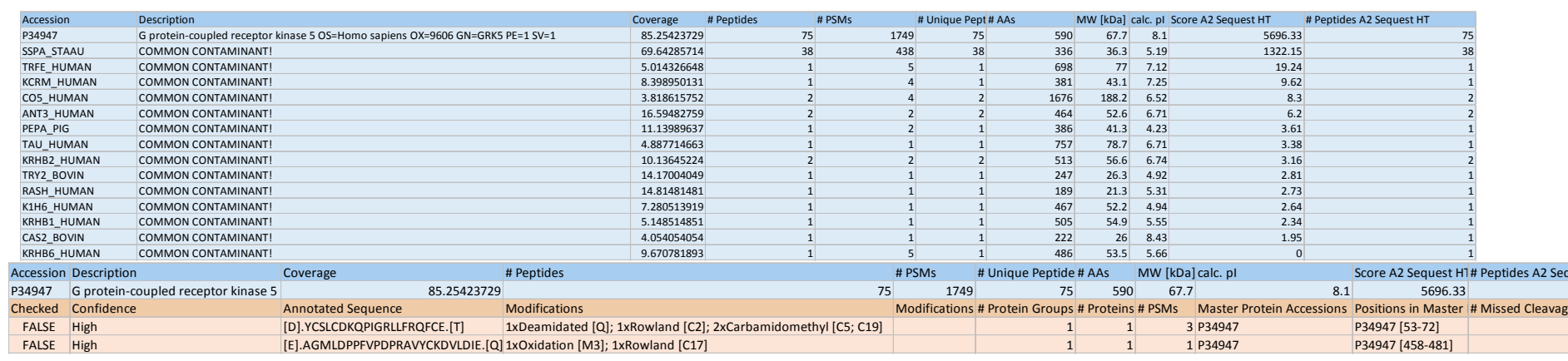

C

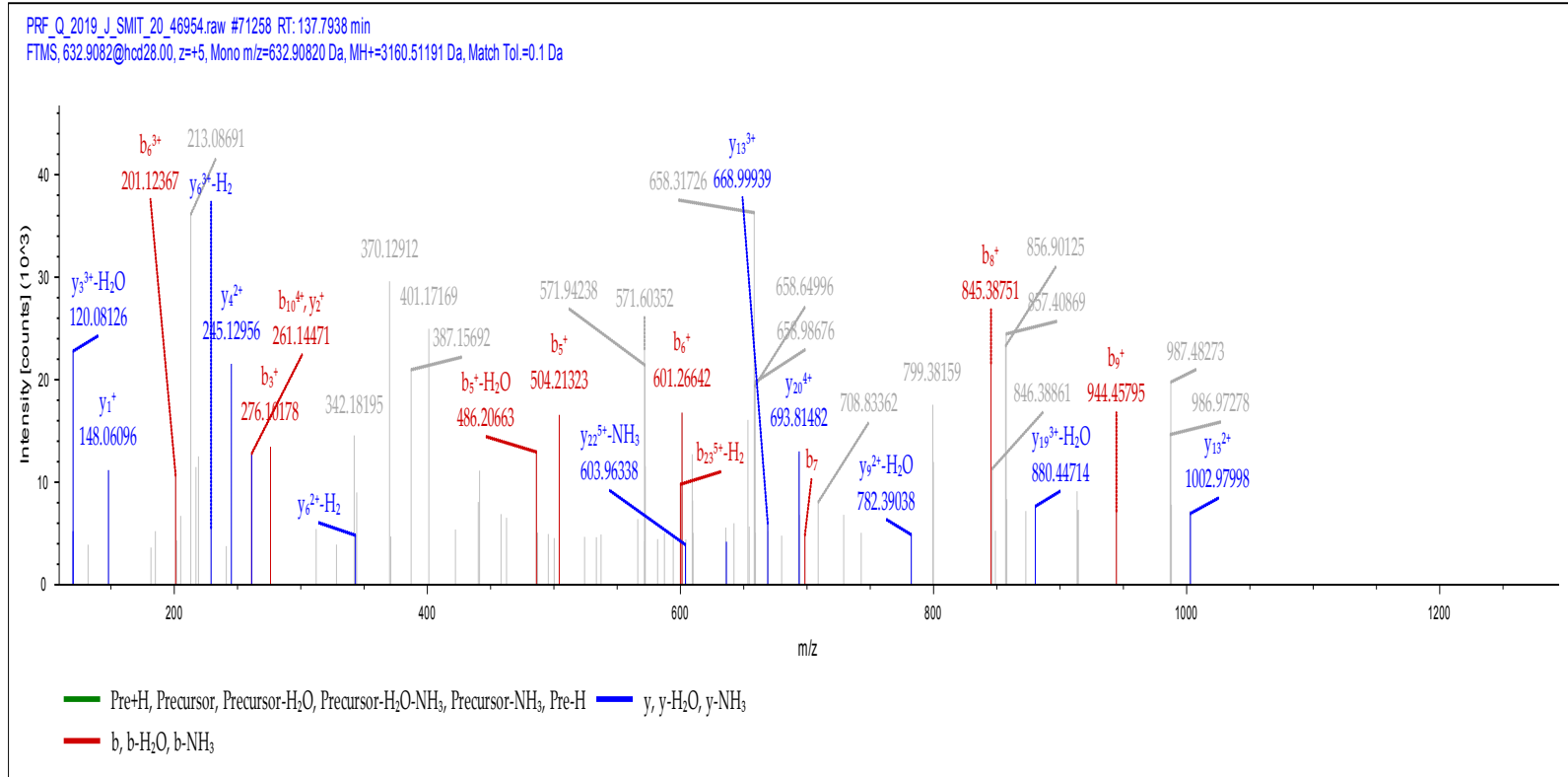

Figure S3. Tandem MS/MS table \& details for hGRK5 incubated with 16d. (A) Tandem MS/MS table of proteins detected in the GRK5.16d sample, indicating that $85 \%$ of the peptides belong to GRK5. (B) GRK5.16d analysis table showing only the modification made to GRK5 by 16d. Our desired modification (denoted "Rowland") is observed at Cys474 with high confidence. Additional modification is observed at Cys54, which likely occurs via a non-selective mechanism. (C) Fragmentation of peptide labeled "Rowlands [C17]". 


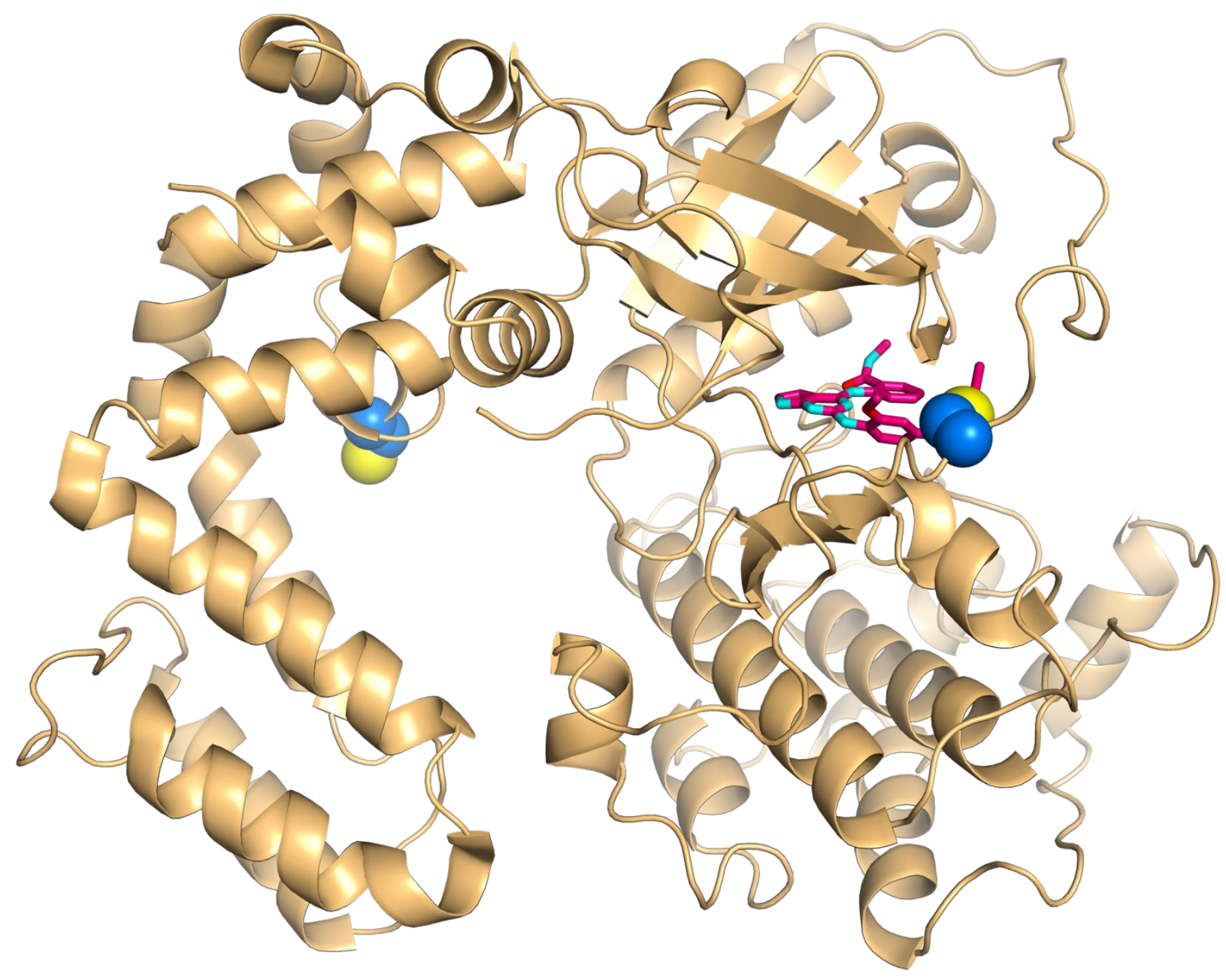

Figure S4. Structural rationalization of tandem MS/MS results. Wild-type GRK5 (blue ribbon diagram) shown with 16d (gold carbons) docked into active site. Cysteine sites of modification identified by tandem MS/MS are shown with sphere side chains (blue carbon,yellow sulfur). Cys54 is in a highly solvent exposed region, suggesting nonselective labelling. ${ }^{5}$ 

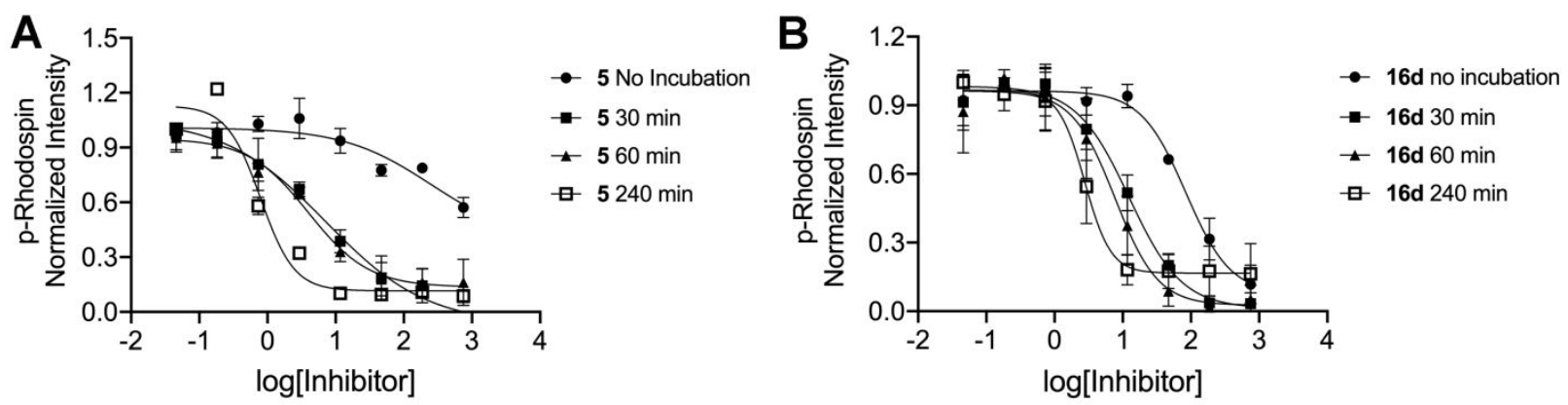

Figure S5. Time dependent inhibition of GRK5 by $\mathbf{5}$ and $\mathbf{1 6 d}$ using light activated ROS as substrate. Compounds were preincubated for times of 0 mins (solid circle), $30 \mathrm{~min}$ (solid square), 60 min (solid triangle) and $240 \mathrm{~min}$ (open square). Both compounds demonstrate the expected leftward shift in $\mathrm{IC}_{50}$ as preincubation time increase, similar to when tubulin is used as substrate (Figure 2). (A) $I C_{50}$ values of 5 at each preincubation time: $\left[I C_{50}\right]_{0 \mathrm{~min}}>100 \mu \mathrm{M},\left[\mathrm{IC}_{50}\right]_{30 \mathrm{~min}}=4.2 \pm 2 \mu \mathrm{M},\left[\mathrm{IC}_{50}\right]_{60 \mathrm{~min}}=3.4 \pm 2 \mu \mathrm{M}$ and $\left[\mathrm{IC}_{50}\right]_{240 \mathrm{~min}}$ $=0.9 \pm 0.2 \mu \mathrm{M}$. (B) $I C_{50}$ values of $16 \mathrm{~d}$ at each preincubation time: $\left[I C_{50}\right]_{0 \text { min }}=91 \pm 20 \mu \mathrm{M}$, $\left[\mathrm{IC}_{50}\right]_{30 \mathrm{~min}}=12 \pm 3 \mu \mathrm{M},\left[\mathrm{IC}_{50}\right]_{60 \mathrm{~min}}=7.6 \pm 4 \mu \mathrm{M}$ and $\left[\mathrm{IC}_{50}\right]_{240 \mathrm{~min}}=2.7 \pm 0.8 \mu \mathrm{M}$. Errors correspond to standard deviation from 2 (panel A) or 3 (panel B) replicates. 


\section{Supplementary References}

(1) Mann, M.; Jensen, O. N. Proteomic Analysis of Post-Translational Modifications. Nat. Biotechnol. 2003, 21, 7.

(2) Gray, N. S.; Hatcher, J.; Choi, H. G. Lrrk2 Inhibitors and Methods of Making and Using the Same. WO2016130920A2, August 18, 2016.

(3) Muthuppalaniappan, M.; Viswanadha, S.; Babu, G.; Vakkalanka, S. K. V. S. Novel 3,5-Disubstituted-3h-Imidazo[4,5-B]Pyridine and 3,5- Disubstituted -3h[1,2,3]Triazolo[4,5-B] Pyridine Compounds as Modulators of Protein Kinases. US2011281865 (A1), November 17, 2011.

(4) Kim, M.-S.; Zhong, J.; Pandey, A. Common Errors in Mass Spectrometry-Based Analysis of Post-Translational Modifications. Proteomics 2016, 16 (5), 700-714. https://doi.org/10.1002/pmic.201500355.

(5) Gehringer, M.; Laufer, S. A. Emerging and Re-Emerging Warheads for Targeted Covalent Inhibitors: Applications in Medicinal Chemistry and Chemical Biology. J. Med. Chem. 2018. https://doi.org/10.1021/acs.jmedchem.8b01153. 